University of Miami Law School Institutional Repository

University of Miami Business Law Review

7-1-2005

\title{
Private Contracting and Business Models of Electronic Commerce
}

Ichiro Kobayashi

Follow this and additional works at: http://repository.law.miami.edu/umblr

Part of the Law Commons

\section{Recommended Citation}

Ichiro Kobayashi, Private Contracting and Business Models of Electronic Commerce, 13 U. Miami Bus. L. Rev. 161 (2014)

Available at: http://repository.law.miami.edu/umblr/vol13/iss2/3

This Article is brought to you for free and open access by Institutional Repository. It has been accepted for inclusion in University of Miami Business

Law Review by an authorized administrator of Institutional Repository. For more information, please contact library@law.miami.edu. 


\title{
PRIVATE CONTRACTING AND BUSINESS MODELS OF ELECTRONIC COMMERCE
}

\author{
ICHIRO KOBAYASHI ${ }^{\star}$
}

TABLE OF CONTENTS

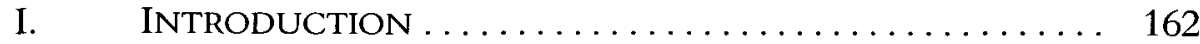

II. ANALYTICAL FRAMEWORK .................. 166

A. Business Models and Private Contracting ............ 166

B. Bilateral Incentive Mechanisms and Informal Norms ....... 171

1. BONDING MECHANISM ............... 172

2. THE ROLE OF THIRD PARTY INTERMEDIATION . . . 175

3. TWO STAGES OF INFORMAL NORMS

CREATED By INCENTIVE MECHANISMS . . . . . . . . 179

4. NORMATIVE IMPLICATIONS $\ldots \ldots \ldots \ldots \ldots \ldots . \ldots 183$

III. EMPIRICAL ANALYSIS $\ldots \ldots \ldots \ldots \ldots \ldots \ldots \ldots \ldots \ldots \ldots$

A. One-to-One Transactions ...................... 187

1. TRADITIONAL EDI (VAN-EDI)-OFFLINE

PAPER CONTRACTS . . ................ 187

2. INTERNET-EDI-FROM PAPER TO ONLINE

CONTRACTS ....................... 189

3. SummarY . ....................... 191

B. One-to-Many Transactions .................... 191

1. ONLINE SHOPPING Sites - BILATERAL

INCENTIVES THROUGH PAYMENT MECHANISMS . . . 191

2. EleCtronic TENDER PROCUREMENT SYSTEMS GOVERNMENT REPUTATION . . . . . . . . . . . 197

3. SUMmaRY ....................... 200

C. Many-to-Many Transactions .................... 201

1. ONLINE SHOPPING MaLlS-MALL'S REPUTATION

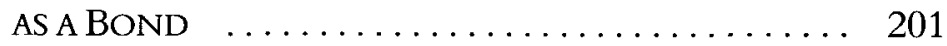

2. E-MARKETPLACES-ESCROW SERVICES .......... 204

3. AUCTION SITES-FEEDBACK SYSTEMS AND ONLINE PAYMENT SYSTEMS . . . . . . . . . . . . . . 207

4. Negotiable INSTRUMENTS - DisCRETE

MEMBER AgreEMENTS $\ldots \ldots \ldots \ldots \ldots \ldots \ldots 211$

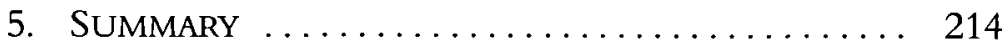

IV. CONCLUSION ........................... 214

Manager, Legal Counsel, Mitsubishi Corporation. LL.M., Columbia University (2003). LL.B., University of Tokyo, Faculty of Law (1994). 


\section{INTRODUCTION}

This article studies incentive mechanisms for business models of electronic commerce and analyzes how incentive mechanisms affect contractual arrangements by private lawmakers in the electronic commerce field. Since the late 1990 s, business people have paid more attention to the term "business model,"and have acknowledged that creative business models could expand their own businesses. ${ }^{1} \quad$ Some business people contemplated creating a new market by utilizing information technology. ${ }^{2}$ Others desired to make their businesses more efficient and less costly by using Internet facilities, and therefore developed business models in the area of electronic commerce. ${ }^{3}$ The proliferation of business model patents also triggered a perception of the importance of creating new business models by businesspeople worldwide. After the United States Court of Appeals officially recognized in 1998 that business model patents deserve patent protection pursuant to the United States Constitution, ${ }^{4}$ many business entities began applying for business model patents. Some were successfully registered. ${ }^{5}$ In

1 The advent of the Internet made business people realize the true importance of business models. The Internet forced businesses to reconfigure their business models; it has changed the way "millions of businesses shop for information, buy and sell goods and services, and participate in discussions." Jeffrey J. Norton \& Noah P. Barsky, Management Control Issues and Legal Concerns Surrounding Business-to-Business E-Commerce: Transactions in the Electric Utility Industry, 21 J.L. \& CoM. 47, 63 (2001) [hereinafter Norton \& Barsky].

2 "Information technology's share of the U.S. economy nearly doubled between 1977 and 1998, growing from 4.2 percent to 8.2 percent. . Information technologies contributed more than a third of real U.S. economic growth between 1995 and 1997." CAROL ANN MEARES, JOHN F. SARGENT, JR., ET. AL., ThE DigITAL WORKFORCE: BUILDING INFOTECH SKILIS AT THE SPEED OF INNOVATION 5 (June 1999), at http://www.ta.doc.gov/Reports/TechPolicy/digital.pdf (last visited Oct. 24, 2004).

3 Electronic commerce "generally refers to contracts and payments made using computers and other electronic equipment." Gregory E. Maggs, Regulating Electronic Commerce, 50 AM. J. COMP. L. 665, 665 (2002) [hereinafter Maggs]. The rise of electronic commerce has "enhanced the abilities of companies to collect, store, transfer, and analyze vast amounts of data." Norton \& Barsky, supra note 1, at 63 .

4 See State Street Bank \& Trust Co. v. Signature Financial Group, Inc., 149 F.3d 1368 (Fed. Cir. 1998).

See Jared Earl Grusd, Intemet Business Methods: What Role Does and Should Patent Law Play?, 4 VA. J. L. \& TECH. 9, para. 5 (1999). Grusd presented many examples of actual business model patents registered during the dot-com boom such as (i) Cybergold's "pay-per-view advertising method," which "may be able to block all methods in which users are offered pecuniary rewards for viewing Internet-based advertisements;" (ii) Slashdot.org's patent concerning "certain aspects of playing three-dimensional games on the Internet;" (iii) Open Market's "secure, real-time payment method over the Internet using debit and credit cards;" (iv) Netcentives's "online frequent-buyer program;" and (v) Netdelivery's "proprietary billing and cataloguing processes." Id. See also Teresa Riordan, A Dangerous Monopoly? Paying Computer Users to Read Intemet Ads and Then Storing Their Data, N.Y. TIMES, Feb. 1, 1999, at C2; Scott Thurm, WALL ST. J., Oct. 9, 1998, at B1; See generally Nicole-Marie Slayton, Intemet Business Model Patents: An Obvious 
1999, Amazon.com obtained a U.S. patent for the one-click online shopping process that places purchase orders via a communications network. ${ }^{6}$ Priceline.com's reverse auction patent also caused a flutter. ${ }^{7}$ The patent permits Priceline.com to exclude all other business methods in which a buyer proposes a price for a product or a service and sellers bid to supply it. ${ }^{8}$ However, althoughHHH numerous Internet companies had funding at the peak of the dot-com boom, only a few business models were successful after the burst of the IT bubble. ${ }^{9}$ Investors massively overestimated the speed at which the marketplace would adopt dot-com innovations. ${ }^{10}$ Why did many new business models disappear from the business world? What are the common characteristics of the successful business model?

Answering these questions not only gives business people direction for implementing new businesses, but also serves to develop a framework for private contracting in the electronic commerce field. Business models are, in a sense, products of parties' procedural mechanism of exchange because business models primarily aim to give contracting parties incentives to reach agreements. Successful business models provide contracting parties with an efficient bilateral incentive to reduce transaction costs. ${ }^{11}$ At the same time,

Incentive to Reform the United States Patent and Trademark Office, 21 LOY. LA. ENT. L. REV. 123 (2000) (discussing business model patents).

6 U.S. Patent 5,960,411 (issued Sept. 28, 1999), http://patft.uspto.gov/netacgi/nphParser?Sect $1=$ PTO1 $\&$ Sect $2=$ HITOFF $\&$ d $=$ PALL $\& \mathrm{p}=1 \& \mathrm{u}=/$ netahtml/srchnum.htm $\& \mathrm{r}=1 \& \mathrm{f}=\mathrm{G} \& \mathrm{l}$ $=50 \& \mathrm{~s} 1=5,960,411 . \mathrm{WKU} \cdot \& \mathrm{OS}=\mathrm{PN} / 5,960,411 \& \mathrm{RS}=\mathrm{PN} / 5,960,411$. Thereafter, in district court, Amazon.com successfully sued Barnesandnoble.com alleging patent infringement. See Amazon.com, Inc. v. Barnesandnoble.com, Inc., 73 F. Supp. $2 d 1228$ (W.D. Wash. 1999). Nevertheless, the United States Court of Appeals for the Federal Circuit vacated and remanded the District Court's decision, and noted that Barnesandnoble.com had "raised substantial question of invalidity" in regards to the patent at issue. Amazon.com, Inc. v. Barnesandnoble.com, Inc. 239 F.3d 1343, 1366 (Fed. Cir. 2001).

1 U.S. Patent 5,794,207 (issued Aug. 11, 1998), http://patft.uspto.gov/netacgi/nphParser?Sect $1=$ PTO1\&Sect $2=$ HITOFF $\& \mathrm{~d}=$ PALL\&p $=1 \& \mathrm{u}=/$ netahtml/srchnum.htm\&r $=1 \& \mathrm{f}=\mathrm{G} \& \mathrm{I}$ $=50 \& \mathrm{~s} 1=5794207 . \mathrm{WKU} \cdot \& \mathrm{OS}=\mathrm{PN} / 5794207 \& \mathrm{RS}=\mathrm{PN} / 5794207$.

8 See Peter H. Lewis, Web Concem Gets Patent For Its Model Of Business, N.Y. Times, Aug. 10, 1998 , at D1.

9 See, e.g., Miguel Helft, Business; Still Alive and Growing Online, Without Fanfare, N.Y. TIMES, Jan. 6,2002 , at Section 3.

10 See id. Helft notes:

[w] hile scores of e-commerce companies have vanished, online retailing continues to grow, and shoppers increasingly expect off-line stores to have online branches. Yet for many traditional retailers, the Internet has been little more than a costly headache. . . [T] raditional chains-including Target, Wal-Mart and Macy's and Bloomingdale's, the Federated Department Stores units-have scaled back, restructured or canceled online efforts.

Id.

1 In the economic literature, scholars have developed an economic model of contractual relationship in which the primary purpose is to economize on transaction costs. See, e.g., Oliver E. 
the incentive mechanisms incorporated in business models are closely linked to relational theory of private contracting. ${ }^{2}$ If drafting costs are so costeffective, and legally enforceable terms addressing contingencies enable contracting parties to achieve efficient allocation of surplus at the stage of legal enforcement, contracting parties may simply rely on a mechanism of legal-enforcement. Where legal enforcement is robust, non-legal incentive devices are not necessarily needed. On the other hand, if contingencies are so unknown or so complicated that drafting legally enforceable terms might not be cost effective, contracting parties are likely to abandon drafting discrete contracts and instead adopt an incentive mechanism.

Accordingly, while this article makes an intensive analysis of electronic commerce business models and their incentive mechanisms, it primarily has two goals. The first goal is to show the close relationship between particular types of contracts and business models. Business models are classified into two types according to which costs, ex ante or ex post, are emphasized as a cost-engineering target. ${ }^{13}$ The first type presupposes that contracting parties are able to draft specific terms and conditions, either online or offline, to respond to anticipated contingencies and enable legal enforcement. In the world where the legal enforcement is cost-effective, contracting parties try

Williamson, Transaction-Cost Economics: The Governance of Contractual Relations, 22 J.L. \& ECON. 233 (1979) [hereinafter Williamson, Transaction-Cost Economics]. Although these discussions have focused on a transaction model where a promisee uses a bond or a hostage posted by a promisor, in most cases, a real transaction is an exchange of assets where two or more parties exchange such bond or hostage bilaterally. This article presumes that the examination of bilateral incentives, rather than a mere unilateral function of each incentive, is necessary for the better understanding of the overall structure of real transactions. See Avery Wiener Katz, Informality as a Bilateral Assurance Mechanism: Comments on Ronald Mann's "The Role of Letters of Credit in Payment Transactions," 98 MICH. L. REv. 2554 (2000) [hereinafter Katz, Bilateral Assurance] (discussing the bilateral assurance mechanisms in letters of credit due to the strong signal of making the letter legally binding). For bonds or hostages, see, e.g., Oliver E. Williamson, Credible Commitments: Using Hostages to Support Exchange, 73 AM. ECON. REv. 519 (1983) [hereinafter Williamson, Credible Commitments] (introducing the norm hostage, and describing the function of the hostage in relational contracts).

12 Stewart Macaulay first identified that contract parties often prefer not to refer to their contracts or legal sanctions when they settle disputes. Steward Macaulay, Non-Contract Relations in Business, $28 \mathrm{AM}$. SOC. REv. 55 (1963). In the legal literature, Ian Macneil and other scholars have demonstrated a model of relational contracts that do not easily fit the classical bargaining models. See, e.g., Ian Macneil, Contracts: Adjustment of Long-Term Economic Relations Under Classical, Neo-Classical, and Relational Contract Law, $72 \mathrm{Nw}$. U. L. REv. 854 (1978); Charles J. Goetz and Robert E. Scott, Principles of Relational Contracts, 67 VA. L. REV. 1089 (1981) [hereinafter Goetz \& Scott]; David Charny, Nonlegal Sanctions in Commercial Relationships, 104 HARV. L. Rev. 375 (1990) [hereinafter Charny].

13 In this article, ex ante transaction costs refer to transaction costs for making contracts (contract specification costs or contract drafting costs) at the stage of pre-contract negotiations. Ex post transaction costs refer to transaction costs incurred at the stage of contract performance, such as enforcement costs and renegotiation costs. 
to minimize drafting costs as well as other administrative costs that arise in the contract negotiation process. The first type of business model responds to such requests of transactors to establish a standardized negotiation or contract formation process with Internet devices. Alternatively, the second type presupposes that contracting parties are unable to specify contingencies because these contingencies are unknown, or even if they are known to contracting parties, are too complicated to be specified efficiently in a contract term. In the regime of extremely high contract specification costs, contracting parties give up forming a discrete contract, and instead rely on cost-effective self-enforcing mechanisms that offer informal norms to secure the contract performance. The second type of business model is counteracted by requiring transactors to incorporate the bonding mechanism into a standardized process of electronic commerce using the Internet. This article will argue that due to the unique nature of electronic commerce, most of the successful business models are categorized as the second type, which incorporates an incentive to enhance self-enforcement by transactors.

The second goal of this article is to reveal the uniqueness of informal norms in electronic commerce. One of the unique natures of business-toconsumer electronic commerce is that it has both high contract specification costs at the contract negotiation stage and high enforcement costs, both legal and non-legal, at the contract enforcement stage, even though other administrative costs are significantly lower. Business models of electronic commerce often require much stronger incentive mechanisms because they are so unique. This creates two stages of informal norms. One is a weak informal norm that mainly functions as a bond or hostage when contracting parties desire to preserve their relationship. ${ }^{14}$ The other is a stronger informal norm that mainly operates when contracting parties wish to settle a dispute with intent to end their relationship, and works as a substitute for, rather than a complement to, the weakness of legal enforcement. This article will conclude that in electronic commerce settings, courts should be more sensitive to the business models underlying the disputed transactions. In cases where underlying business models emphasize creating incentive mechanisms to enhance self-enforcement by contracting parties, courts should use a formalistic interpretation of contract language as long as the business models attain efficient allocation of formal and informal norms as a result of incorporating incentives.

This article has three remaining parts. Part II sets out the analytical framework. As an analytical framework, subsection A outlines the inter-

14 For a detailed classification of non-legal sanction using bond or hostage mechanisms, see, for example, Charny, supra note 12, at 392-97 (classifying the non-legal sanction into three types: relationspecific prospective advantages, reputation in the market, and social and psychic losses). 
relationship mechanism between business models and private contracting, and subsection $\mathrm{B}$ describes the mechanism in which incentives in business models create informal norms. Part III presents empirical analysis of currently prevailing business models, and reveals how parties choose formal and informal norms in contract formation under the influence of incentive mechanisms underlying business models. In analyzing business models, a new transactional classification of one-to-one, one-to-many, and many-tomany, according to the potential number of players in a business model, is also used as an analytical framework. Part IV summarizes the analysis and offers a conclusion.

\section{ANAL YTICAL FRAMEWORK}

\section{A. Business Models and Private Contracting}

The term "business model," although abstract and vague, "typically describes a firm's unique combination of products or services, its legal and financial structure, operations, supply chain to and from the firm, transactional forms, terms of trade, marketing activities, management style, and accounting systems." ${ }^{15}$ However, since this article aims to discover how business models affect private contracting in the electronic commerce setting, the business model is viewed from the perspective of institutional economics. ${ }^{16}$ In this respect, the business model refers to a particular formal and widely available structure of incentives that makes up the institutional framework. More concretely, this article defines that the business model is a unified and standardized process containing an incentive mechanism in which two or more strangers seek to exchange assets, conduct negotiations, reach an agreement, and finally execute asset exchange efficiently in accordance with contract terms. This article assumes that such incentive mechanisms are those that provide two unknown parties with efficient tools to solve information asymmetry problems with the lowest transaction costs,

15 John W. Bagby, Business Method Patent Proliferation: Convergence of Transactional Analytics and Technical Scientifics, 56 BUS. LAW. 423, 445 (2000) (discussing various issues concerning a business methods patent).

16 See generally Ronald J. Mann, Verification Institutions in Financing Transactions, 87 GEO. L. J. 2225 (1999) [hereinafter Mann, Verification Institutions in Financing Transactions] (stating that institutional economics presumes that the supply and demand analysis cannot completely explain the economic development, and claiming that efficiency of institutions will be an essential part of the success of a business). 
which mainly consist of ex ante negotiation costs and ex post enforcement (renegotiation and dispute resolution) costs. ${ }^{17}$

The Internet's low barriers to conducting business enable parties to participate in smaller transactions. ${ }^{18}$ Some argue that administration costs are significantly lower in electronic commerce because of the Internet's global nature. ${ }^{19}$ Due to the globalization of Internet transactions, contracting parties in different countries can pursue international transactions more easily than before the Internet existed. ${ }^{20}$ However, while the nature of Internet transactions increases the possibility of long-distance transactions, the transactions do not necessarily reduce contract negotiation costs. Although the geographic openness of electronic commerce makes stranger-to-stranger transactions more likely, the lack of face-to-face contact in the negotiation process makes negotiation costs much higher when contracting parties wish to write complete contracts. Contract negotiations need to be flexible and heterogeneous. When paper based transactions are implemented with longdistance transactions, negotiations are mainly made by exchanging draft contracts via communication devices like e-mail, telex, or facsimile. If contracting parties wish to make their negotiation process more standardized and automated through a Web-based electronic commerce interface however, face-to-face or real time negotiations are no longer expected.

To illustrate how the lack of face-to-face contact or real time communication makes negotiation costs much higher, suppose there is a simple paper-based transaction in which a seller would like to sell a product to a buyer. In the real world, the seller would first find potential buyers. One might advertise his or her goods in public newspapers, while others might obtain a list of potential buyers from an information source and send direct mails for solicitation. The seller then selects a buyer and commences negotiations. During negotiations, one party proposes a draft contract to the other, and the party receiving the first draft reviews it and proposes a counteroffer. Drafts undergo several revisions until the contract is finalized. In general, the negotiation process for larger deals is likely to become lengthier and more complicated. For example, in a typical acquisition agreement, the owner of a target company, often in advance, submits information memorandums to several potential buyers that detail the bidding process and

17 See generally $i d$. (taking a similar approach in his observation of financial transactions and explaining the informational verification mechanism in financing transactions).

18 Henry H. Perritt, Jr., Dispute Resolution in Cyberspace: Demand for New Forms of ADR, 15 OHIO ST. J. ON DISP. ReSOL. 675, 675 (2000) [hereinafter Perritt] (discussing the criteria for further development of alternative dispute resolution (ADR)).

19 See id. at 675-76.

$20 \quad$ See id. at 675. 
its conditions. ${ }^{21}$ After the bid opens, some of the bidders are short-listed and the target's owner and the potential buyer begin negotiations by entering into a non-binding letter of intent.

In contrast, electronic commerce negotiation is rapid and more standardized. In many cases, no substantive negotiation occurs until executing the standardized contracts. Parties first determine whether they should enter into a transaction by considering information provided both online and offline. While the rapid and standardized character of electronic commerce substantially reduces direct administration costs, substantive contract negotiations are more difficult. This means that transaction costs for executing complete contracts (contract drafting costs) are relatively high. ${ }^{22}$ While real time negotiation makes flexible contract drafting possible by reflecting oral conversation into contract terms directly and instantly, parties under electronic commerce usually do not conduct such real time negotiations.

Due to high drafting costs, contracting parties often encounter difficulty in reaching discrete contracts. When contracting parties are unable to address contingencies underlying the transaction in specific terms, they have difficulty in seeking legal enforcement. Courts often interpret commitments not addressed in the face of a contract as unenforceable, or at least the commitments face uncertainty with court interpretation. Thus, contracting parties must rely on alternative mechanisms of self-enforcement in which informal norms mainly function to settle disputes ex post. In a regime where legal enforcement is not available, contracting parties must try to rely on mutually trusting each other, but the level of trust is uncertain at the time of forming a contract. A party faces the risk of opportunistic conduct, or rentseeking behavior of its counterpart. Since one party often encounters the risk of the other party's rent-seeking in the regime of incomplete contracts, contracting parties often establish a mechanism for the other party to promise

21 See, e.g., Dale A. Oesterle, The Law of Mergers and Acquisitions, American Casebook Series, Westgroup 9-17 ( $2 \mathrm{~d}$ ed.) (describing the M\&A negotiation process).

22 In this respect, drafting costs differ according to type of transaction. For example, drafting costs are minimal in a standardized business-to-consumer transaction where contingencies are highly regulated by the background rules, including the Uniform Commercial Code. In such transactions, businesses reduce the background rules to the printed-terms of agreements with minimal costs-although it is still costly for consumers to read or modify such printed terms. For other types of agreements, mainly in business-to-business transactions, contracting parties may face greater drafting costs when they want to specify complex terms. However, such costs are not necessarily unbearable for businesses if the transaction amount or volume is much greater as compared to drafting costs. This article presumes that in the electronic commerce setting, drafting costs are relatively high - at least for businesses in businessto-business transactions where flexible negotiations are sought, and for consumers in business-toconsumer transactions, where consumers have no means of amending the printed-terms. For the brief analysis of drafting costs, see Charny, supra note 12 , at 403-04. 
not to engage in such rent-seeking behavior. ${ }^{23}$ In this context, incentive mechanisms, in a sense, aim to fill a gap between formal legal norms and transactional substance.

Even though parties successfully address all anticipated contingencies in detailed contractual terms by creating in electronic commerce a standardized system of efficient negotiation that significantly reduces drafting costs, lower values of electronic commerce prevent legal enforcement because legal enforcement ex post is more costly than the value of a subject matter. Contracting parties recognize that enforcement costs are often too high vis-à-vis the value of transactions. The National White Collar Crime Center ("NW3C") showed that, for complaints reported to IFCC as fraud cases from January 1 to December 31, 2004, the mean amount of loss was $\$ 894.26$ and the median amount of loss was $\$ 219.56 .{ }^{24}$ NW3C estimates that "just over $87.7 \%$ of all fraud complaints are related to the Internet or online service." ${ }^{25}$ It is a crucial factor for successful business models to have sufficient incentive tools to reduce anticipated ex post self-enforcement costs. When contracting parties find it infeasible to resort to legal enforcement because of high drafting costs, or even if the drafting cost problem was solved, because of the lower-value problem, contracting parties in electronic commerce then rely on an alternative self-enforcing mechanism.

However, electronic commerce often increases parties' self-enforcement costs for many reasons. As electronic commerce often has its basis on longdistance and stranger-to-stranger transactions, it encounters difficulty in creating an efficient mechanism of reputation as a bond. Reputation works well if it is disseminated to a particular community easily and quickly, and there is a well-established system to monitor it, ${ }^{26}$ but electronic commerce

23 See Avery Wiener Katz, The Economics of Form and Substance in Contract Interpretation, 104 COLUM. L. REV. 496, 530-32 (2004) [hereinafter Katz, Form and Substance]. Generally, "rent seeking can take place at the contract-writing stage." Id. at 531. If the contract is incomplete and thus more substantive interpretation is required, contracting parties' options are either (i) to invest a substantial amount of resources in prospective litigation to maximize the possibility of a favorable outcome or (ii) to write a discrete contract where the slight productivity of such litigation expenditures are reduced, minimizing the total litigation expenditure. Id. at 530-31. However, in the electronic commerce setting, the investment resource for writing efficient terms of discrete contracts is limited, and thus standard form contracts are used in most cases. Cf. id. Under the transaction where a party's standard contract form is used, those who propose such standard form contracts "will be tempted to sneak one-sided but inefficient terms into the contract." Id. Accordingly, contracting parties "would find it useful to have a way of committing to abstain from such behavior." Id.

24 National White Collar Crime Center \& FBI, IFCC 2002 Internet Fraud Repont (Jan. 1, 2004 Dec. 31, 2004), available at http://www.ifccfbi.gov/strategy/2004_IC3Report.pdf (last visited April 11, 2005).

$25 I d$. , http://www.ifccfbi.gov/strategy/2004_IC3Report.pdf at 5.

26 For general discussions of reputational non-legal sanction mechanisms, see Charny, supra note 
often does not fulfill these two preconditions. Forming a community in which reputation functions efficiently is often difficult due to the longdistance and global nature of electronic commerce. Due to the stranger-tostranger nature of electronic commerce, one may not easily create a transactor's reputation. For instance, auction site players generally deal with each other in the regime where information is incomplete, or even if the information is available, none may verify it. Further, stranger-to-stranger deals in electronic commerce premise spot deals rather than repeat deals. While in repeat deals a future transaction opportunity may function as a relation specific bond, contracting parties in spot transactions generally have no means to exchange a relation specific hostage solely for such one shot transactions.

In sum, contracting parties in electronic commerce bear high transaction costs for establishing both legal and non-legal enforcement mechanisms. In the ex ante contract negotiation stage, electronic commerce's global and longdistance nature and standardized, automated, and impersonal nature make drafting costs much greater than those in paper-based transactions. In the $e x$ post enforcement stage, it then encounters the lower-value problem. Even if electronic commerce successfully implements a system of reducing contract specification costs, legal enforcement is not justified because litigation costs do not outweigh the expected amount of recovery. Even though contracting parties may decide to shift their contract regime to a more incomplete one, they may encounter difficulty in creating efficient bonds because the longdistance and the stranger-to-stranger natures make costs of creating bonds much higher.

Business models are thus developed in order to solve the above problems. This hypothesis suggests the following typology for business models of electronic commerce. First, business models are classified according to whether they seek legal enforcement by reducing drafting costs. In this respect, most of the business models will fail to establish such drafting cost reduction systems because the standardized, automated, and impersonal nature of the interface makes it difficult to establish an effective structure of contract negotiation and flexible drafting mechanisms. At most, only a transaction that is highly standardized in the form of contracts, and in which most contingencies are known, is eligible for creating such cost-effective negotiation mechanisms. Letters of credit or bills of lading are probably the most typical illustration. As these contracts are already highly standardized and focal points of negotiation are pre-determined, these are more easily incorporated into an automated system of business models without the intervention of human discretion. Except for such rare cases, most of the business models will fail to establish the regime of discrete contracts. Instead, the primary concern for businesses that operate Web site electronic 
commerce is how to implement effective self-enforcing mechanisms. In order to achieve this goal, business models often require transactors to exchange bonds or hostages that encourage the substantive performance of contracts. ${ }^{27}$ As discussed in Part III, operators of electronic commerce invented various bonding mechanisms, such as credit card chargeback systems, online payment mechanisms, electronic money, escrow services, and online feedback systems.

Finally, if the business models already solve the problem of high selfenforcement costs, they may be able to focus on minimizing other administrative costs, such as delivery or transportation costs. In such business models, the primary users may be those in relatively high value transactions (anticipated litigation costs are relatively lower vis-à-vis the transaction value) or those relational parties who desire to continue their business relationship or engage in many similar transactions regularly, or those who expect to have symmetric information ex post regarding the costs and benefits of performance (renegotiation costs are expected to be lower). ${ }^{28}$ The typical example of high value transactions is an electronic tender system implemented by a government office or entity. Presumably, governmental electronic tender systems primarily intend to reduce various administrative costs, including contract specification costs, in connection with the tendering process. ${ }^{29}$ The illustration of a two relational parties' transaction is a traditional EDI platform, where the two parties' relationship already minimized litigation risks and reduced renegotiation costs sufficiently before they went online. ${ }^{30}$ Since relational parties, through their experience of similar transactions in the past, may identify legal contingencies more easily, parties may be able to address those contingencies in their EDI contracts on an offline, paper basis. Further, since EDI transactions premise that repeat deals are a relation specific asset exchange, business models do not require additional bonding mechanisms online. Thus, the business models of EDI may focus exclusively on minimizing other administrative costs, the reduction of which may be achieved only by rapid and standardized processes using the Internet.

\section{B. Bilateral Incentive Mechanisms and Informal Norms}

Theoretically, contracting parties optimally choose formal and informal norms in electronic commerce as well as in paper-based transactions. ${ }^{31}$ In the

\footnotetext{
See Williamson, Credible Commitments, supra note 11.

See Katz, Form and Substance, supra note 23.

See infra Part III.C.2.

See infra Part III.B.1.

See Lisa Bernstein, Merchant Law in a Merchant Court: Rethinking the Code's Search for Immanent Business Norms, 144 U. PA. L. REv. 1765 (1996) [hereinafter Bernstein].
} 
contract interpretation of real world transactions, contracting parties allocate aspects of their contracting relationship to formal, legal norms and informal, non-legal norms. ${ }^{32}$ Non-legal sanctions, such as reputation bonds, are sometimes strong enough to ensure the substantive performance of counterparties, making legally enforceable contracts less necessary. ${ }^{33}$

Suppose that a seller repeatedly sells machines to buyers and the seller regularly accepts refunds out of concern for his reputation. The seller does not desire to include in a contract a clause that the seller accepts any refund because the clause may not give the buyer incentives to use the machine in an appropriate manner. Contracting parties do not explicitly write the seller's refund policy in their contract. Put another way, parties intentionally write stricter contract terms, and the fair distribution of costs and benefits is delegated to a flexible application of informal norms. Transactional substance is expelled out of the formal legal regime, and contracting parties create non-legal norms to reflect any substance.

Similarly, in electronic commerce, contracting parties desire to achieve optimal balance of formal and informal norms. However, since formal norms are relatively weak in electronic commerce due to the difficulty of contract enforcement, contracting parties must rely more intensely on informal norms than those in paper-based transactions. In other words, parties must rely on a stronger incentive mechanism that creates stronger informal norms.

\section{BONDING MECHANISM}

The most popular incentive mechanism is the use of bonds or hostages. ${ }^{34}$ This mechanism is triggered by poor contract performance and results in the sacrifice of something valuable - a bond posted by that party. ${ }^{35}$ Two aspects are noted. Ex ante, a contracting party tries to verify information asserted by

32 See id. at $1787-95$.

33 See id. at 1787.

34 See Williamson, Credible Commitments, supra note 11 (describing the terms bonds and hostages).

35 See Charny, supra note 12, at 390-97. There are three types of bonds. The first type is the relationship-specific prospective advantage, where a committing party (promisor) places a particular asset under the control of the other party (promisee). The promisee will forfeit the asset when the promisor breaches. The second type is a party's use of its reputation as a bond. The incentive mechanism is that the promisor develops a reputation on which potential transactors may rely. "If the promisor improperly breaches his commitments, he damages his reputation and thereby loses valuable opportunities for future trade." Id. at 393. Third, the sacrifice of psychic and social goods can be a typical non-legal sanction. For example, when a promisor breaches a contract, he may suffer from "loss of opportunities for important or pleasurable associations with others, loss of self-esteem, feelings of guilt, or an unfulfilled desire to think of himself as trustworthy and competent." Id. at 393-94. 
the counter-party and evaluate the transactional risks via the signal strengths of the posted bonds. In this sense, bonding mechanisms function as an essential tool for contracting parties' risk planning. This aspect is described as an informational verification process, where the first order information (e.g., the obligor's assertion that it has a sound financial standing) is often verified by the second order information provided by a third party intermediary (e.g., an auditor's assertion that the obligor's financial information is true and correct). ${ }^{36}$ On the other hand, an ex post forfeiture of bonds is considered an informal sanction. Contracting parties are encouraged to perform their contract obligation substantively or try to dissolve disputes faithfully for fear of the sanction of losing a valuable asset. In this sense, bonding mechanisms function most effectively when contracting parties desire to use informal norms to resolve contract disputes without ending their transactional relationship.

Hard Assets as Bonds: A classical bonding mechanism is for an obligor to post specific assets as collateral. ${ }^{37}$ By posting collateral, the obligor increases his or her credibility and causes the creditor to have more faith in the obligor. Collateral is classified further into the possessory secured transaction and the non-possessory transaction. ${ }^{38}$

The typical possessory secured transaction is a pledge in which an obligor posts collateral into the possession of a creditor. However, this possessory type of collateral often does not function as an effective bond. ${ }^{39}$ For example, suppose there is a sales transaction in which a seller is a highly reputed manufacturer in sound financial condition and a buyer is an anonymous individual consumer. In this transaction, posting a deposit as collateral to the seller may work as a bond. Nevertheless, the deposit's function as a bond is imperfect unless loss of the deposit imposes a significant loss to the buyer. This type of collateral certainly reduces total risk exposure of sellers, but the bond is often weak if the amount of the deposit is much smaller than the transaction value. As long as the loss of collateral does not threaten an obligor with significant losses, the collateral will not work effectively as a bond.

Under the non-possessory secured transaction, an obligor retains the possession of collateral and files it in public record so that third parties have notice of the creditor's claim against the collateral. ${ }^{40}$ The typical illustration of the non-possessory secured transaction is a mortgaged loan, in which a 
lender obtains a mortgage by use of a loan on the borrower's property. Unlike the possessory secured transaction, the non-possessory secured transaction enables collateral to function more effectively as a bond. ${ }^{41}$ A creditor's threat to enforce collateral is an effective bonding device if the subject of the collateral is an essential part of the obligor's business or personal life. ${ }^{42}$ Thus, the non-possessory secured transaction is more popular than the possessory secured transaction in the real transactional world. ${ }^{43}$

However, even though a business can use such possessory or nonpossessory collateral as a bond, such use is significantly restricted and limited in the field of electronic commerce. The main reason is that secured transactions incur higher transaction costs in electronic commerce. In many cases, both non-possessory and possessory secured transactions inevitably require an additional offline procedure of posting collateral. Further, nonpossessory collateral is more complicated in its creation and thus is less suitable to electronic commerce than possessory collateral, although nonpossessory collateral has more power as a bond. In most cases, non-possessory collateral must be accompanied with some offline paper-based documentation, which may destroy the potential advantage of electronic commerce that enables strangers to reach an agreement only via an online process, while possessory collateral merely requires posting of assets.

Soft Assets as Bonds: While collateral is one of the typical hostages of "hard" assets, information constitutes a "soft" type of hostage. Information is more suitable to electronic commerce than collateral because transactors are able to exchange information online at cheaper costs. If transactors expect the information to work effectively as a bond, such information must constitute reputation, the loss of which will cause a significant damage to an obligor. Reputation functions as a bond to the extent that the failure of the contracting party to perform contract obligations will seriously destroy the party's reputation.

41 In this respect, a relation-specific investment is categorized as a deviation from non-possessory collateral bonds, while the mere relation-specific investment does not legally function as collateral. A relation-specific investment makes an obligor retain possession of the investment, but if an obligor breaches a contract, the investment will lose value.

42 Cf. Robert E. Scott, A Relational Theory of Secured Financing, 86 ColUM. L. REV. 901, 929-30 (1986). The quality of the bond will generally affect the function of the bonding mechanism. An efficient bond should constrain an obligor more strictly. Thus, collateral as a bond is more efficient when the collateral posted is closely related to the obligor's business or personal life. In addition, the bond should not tempt the creditor. If the assets posted as a bond can be readily resold, the creditor will have more incentive to "induce breach, declare default, and sell the [assets]." Id. at 930.

43 See Mann, Verification Institutions in Financing Transactions, supra note 16, at 2243 (explaining informational verification mechanism in financing transactions). 
In electronic commerce, reputation typically works in two cases. First, a reputational capital of an electronic commerce operator gives a strong signal that the operator will perform its contract obligation substantively. Because the operator's business heavily relies on such reputational capital developed through historical achievement, the loss of the capital will seriously affect the business's future operation. Second, information provided by financial intermediaries or credit-related information providers often functions as a reputational bond if the financial reputation is crucial for transactors to maintain their operation, or for individual consumers to maintain their funding source. In typical business-to-consumer transactions, a consumer's credit history particularly functions as a reputational bond. If the consumer fails to perform a contract substantively, failure is recorded in the consumer's credit history. Bad credit history will affect a consumer's ability to obtain sufficient credit in the future.

\section{THE ROLE OF THIRD PARTY INTERMEDIATION}

The previous subsection suggested that, for the purpose of relationspecific asset exchange, an intangible soft asset of information was more suitable to electronic commerce than the hard asset of collateral and, in order for soft information to work as a bond, contracting parties often select a third party as an intermediary with strong reputational signals. However, the function of the third party intermediary is not limited to being a mere information provider serving as a reputational intermediary. In fact, such a party often operates as a direct risk absorber rather than a reputational intermediary. Contracting parties choose appropriate incentives from among the multiple functions of a third party intermediary. For purposes of this article, the mixture of the variety of incentive functions of a third party intermediary is an intermediation.

A common intermediation scheme is the use of guarantees. Although it is widely acknowledged that guarantees primarily have a guarantor bearing the risks of an obligor as a risk absorber, the guarantee mechanism is more complicated. ${ }^{44}$ Let's assume that the creditor's transaction costs are primarily costs of monitoring the obligor (monitoring costs), and costs that the creditor may recognize by multiplying the anticipated amount of loss when the obligor is insolvent by the probability that such insolvency will occur (default

44 See, e.g., Avery Wiener Katz, An Economic Analysis of the Guaranty Contract, 66 U. CHI. L. Rev. 47 (1999) [hereinafter Katz, An Economic Analysis of the Guaranty Contract] (outlining the basic economic logic underlying the guaranty relationship, and applying the results to a variety of specific issues in government policy and private planning). 
risk costs). ${ }^{45}$ By the guarantee scheme, monitoring costs and default risk costs vis-à-vis the obligor will, all or partly, shift to the guarantor. ${ }^{46}$ The creditor, in return, may incur additional administrative costs for selecting this three-party guarantee scheme by either paying a guarantee fee (when the guarantor hedges its costs to the creditor), or decreasing the interest rate (when the guarantor hedges its costs to the obligor). ${ }^{47}$ Obviously the creditor prefers the guarantee when the creditor's cost savings by shifting its monitoring and default risk costs to the guarantor outweigh the creditor's additional costs of having the guarantor undertake the obligor's obligation. To this effect, the creditor's additional administrative costs for selecting a guarantee rather than a single loan are closely linked to the degree of the addition of the guarantor's costs for monitoring the obligor instead of the creditor, and the guarantor's costs of bearing the obligor's default risk. ${ }^{48}$ More concisely, the guarantee scheme is justified when and only when it achieves the three parties' total cost reduction effect by shifting all or part of the creditor's costs to the guarantor.

Two explanations are possible when the guarantee scheme has total cost reduction effects. First, the guarantor may monitor the obligor more costeffectively than the creditor does. In this first scenario, the decrease of the creditor's monitoring costs outweighs the increase of the guarantor's monitoring costs. Second, even if the guarantor does not monitor the obligor effectively, the guarantor's financial commitment may function as a reputation bond that gives the obligor an incentive to comply with the contract obligation. This significantly reduces the creditor's costs of default risks.

Even if the reputation of a guarantor, however, is so strong that a creditor is satisfied with the guarantor's risk taking or even if the guarantor's commitment constitutes a strong bonding mechanism that induces the obligor to perform the contract substantively, the function of the guarantor as an intermediary is still insufficient due to the unilateral function of the guarantee intermediation. This means that a creditor may verify an obligor, but an obligor may not verify an obligor. A guarantee scheme may fit well with a simple loan. Once a loan is made by a creditor, only the creditor bears risks underlying the loan. Indeed, most commercial loan agreements primarily

$47 \quad$ See id. at 69.

48 See id. at 68-70. 
focus on establishing monitoring mechanisms, like affirmative and negative covenants, to prevent a moral hazard problem of the obligor. ${ }^{49}$

Since sales transactions consist of bilateral rights and obligations, contracting parties ask a third party intermediary to work bilaterally rather than unilaterally. In order to deploy the bilateral bonding mechanism, contracting parties often want a third party to intermediate sales transactions by being a direct contract party to the sales transaction rather than merely being a guarantor. ${ }^{50}$ In this "complete intermediation" model, the third party enters into a purchase contract with the seller and simultaneously enters into a back-to-back based contract with the buyer. ${ }^{51}$

An intermediary absorbs contractual risks by dividing a sales contract into two parts; one is between the seller and the intermediary, and the other is between the intermediary and the buyer. In the complete intermediation model, in other words, both the seller and the buyer may shift the target of their monitoring and default risk costs to the intermediary. Similar to the guarantee scheme, the complete intermediation is preferred only when the shift of monitoring and risk targeting will decrease the total transaction costs of the seller, the buyer, and the intermediary. Thus, an analysis of the effect of cost shifting on each party's transaction costs is necessary. From the seller or the buyer's perspective, the seller's (the buyer's) shift of monitoring and risk target from the buyer to the intermediary will release the seller (the buyer) from bearing costs of monitoring the buyer (the seller) and costs of the buyer's (the seller's) anticipated default risks, and will assume additional costs of monitoring the intermediary and costs of the intermediary's default risk. From the intermediary's perspective, on the other hand, the intermediary bears costs of monitoring the buyer and the seller and costs of the seller's and the buyer's default risks. This simple model suggests that contracting parties prefer the complete intermediation when (i) both the seller and the buyer may be able to monitor the intermediary less expensively than they may monitor each other, or more simply, costs of the inter-

49 For typical provisions in loan agreements for U.S. banks, see for example, Kenneth J. Goldberg, Lender Liability and Good Faith, 68 B.U. L. REv. 653 (1988); Robert M. Lloyd, Financial Covenants in Commercial Loan Documentation: Uses and Limitations, 58 TENN. L. REv. 335, $340-43$ (1991).

50 See Ronald J. Mann, Information Technology and Non-legal Sanctions in Financing Transactions, 54 VAND. L. REV. 1627, 1642-48 (2001). Intermediaries play an important role in the field of financial transactions. For example, a securitized transaction implements a mechanism where a third party intermediary "pools the transactions and sells small interests in the pool as a whole." Id. at 1644. The intermediary represents the obligations contained in the pool that backs the securities. In order to verify underlying obligations, the investors rely on assertions by the intermediary rather than examine the underlying obligations by themselves.

51 Cf. Katz, An Economic Analysis of the Guaranty Contract, supra note 44, at 47-90 (analyzing when the parties to a financial transaction choose guarantees rather than intermediation). 
mediary's default is much lower than those of each other's default, and (ii) the intermediary may monitor both the seller and the buyer so costeffectively (thus costs of their default risks also decrease as a result of a strong monitoring) that both parties' switching their costs target to the intermediary realizes total costs reduction effects, or even if the intermediary does not monitor the counterpart effectively, the intermediation gives both the seller and the buyer an incentive to perform a contract substantively so that costs of their default risks become significantly lower.

Thus, the intermediary is often selected from among individuals or entities who have robust reputation and financial credibility and who may monitor both the seller and the buyer cost-effectively or induce substantive performance of the seller and buyer. For instance, if the third party intermediary is a "key player" in the relevant commodity market, the function of the third party's intermediation is robust. From the seller's perspective, the seller may reduce its monitoring costs and default risk costs by shifting its costs target from the buyer to the intermediary if the reputation and the financial credibility of the intermediary are stronger than those of the buyer. Total costs of the seller and the intermediary will decrease if the intermediary may monitor or collect from the buyer more cost-effectively. From the buyer's perspective, on the other hand, the intermediation gives the seller a strong incentive to perform substantively since the seller is afraid that poor performance might destroy a business relationship with the key player in the market. As long as one of the primary concerns for a buyer is whether he will be able to take delivery successfully in accordance with the contract terms, the buyer may feel that seeking indemnification against a reputed third party at the ex post enforcement stage is insufficient. An ex ante mechanism that prevents the seller's rent-seeking behavior and poor performance must also be established. Thus, like a guarantee scheme, an intermediation is stronger if the seller regularly transacts with the third party intermediary and the destruction of the relationship with it will seriously damage the seller's future business.

A distributorship is a common example of this complete intermediation model. When a manufacturer would like to export his products overseas, the manufacturer often tries to appoint an overseas company as a sole distributor of the products. In many cases, manufacturers favor using a distributorship scheme when the overseas company has strong expertise in marketing in the overseas country. ${ }^{52}$ However, such strong expertise is not the sole advantage 
of the distributorship scheme. A manufacturer takes advantage of the distributor's high reputation and credit ratings in order to avoid the end user's non-payment risk. ${ }^{53}$ Similarly, overseas end-users assume that the distributorship by a highly reputed firm constitutes a strong signal that induces the substantive performance of a foreign manufacturer. End-users think that a foreign manufacturer is encouraged to perform a contract substantively for fear of destroying a relationship with an important business partner in the new overseas market. Further, they also think that the distributor will have strong incentives to monitor a foreign manufacturer more carefully because the poor performance of the foreign manufacturer will also damage the distributor's own reputation. In sum, a particular third party's intermediating a transaction scheme is one of the most cost-effective means to create a bilateral incentive mechanism.

\section{Two Stages of INFORMal NORMS CREATED BY INCENTIVE MECHANISMS}

As discussed above, close examination of the traditional incentive mechanisms implemented in real world transactions shows that intermediation and reputation are effective tools in electronic commerce. The reason is simple. As electronic commerce is premised on online transactions between two anonymous parties, two conditions are essential for the development of electronic commerce: (i) soft is better than hard as a hostage because hard assets inevitably require additional offline procedures and (ii) bilateral is more desirable than unilateral assurance mechanisms because both sellers and buyers need to verify each other due to the anonymous nature of

53 See, e.g., Chibli Mallat, Commercial Law in the Middle East: Between Classical Transactions and Modem Business, 48 AM. J. COMP. L. 81 (2000). When a product of a foreign manufacturer attains popularity in a particular country via a domestic distributor's effort, a principal foreign manufacture may try to exclude the distributor from the distribution channels. If the principal manufacturer obtains a good reputation in the respective market, the manufacturer may no longer need the function of intermediation as a reputational bond. Accordingly, many developing countries implement agency law, which regulates the relationship between a principal and a distributor or agency. For example, typical statutes in the Middle East provide for (i) an agent's right to receive commission on transactions that are concluded without the effort's of the agent, (ii) restriction on a principal to terminate the agency agreement without good cause, and (iii) an agent's right to compensation in the event of an inopportune termination of an agency agreement without good cause. Id. at 106. The principal's refusal to renew an agent's contract without proof of the agent's wrong justifying non-renewal shall constitute an abusive exercise of rights entailing appropriate compensation. Id. The agent shall also be entitled to an appropriate compensation if the agent's efforts as the commercial representative have led to success in the principal's business and the principal's refusal to renew the agency contract has prevented the agent from reaping the profits of his success. Id. at 107. 
electronic commerce. ${ }^{54}$ Reputation and third party intermediation are the mechanisms that fulfill these two conditions.

Incentives created by reputation and third party intermediation in turn create informal norms. In this respect, incentive mechanisms classify the transactional norms into the relationship-preserving norms and the end-game norms. ${ }^{55}$ Relationship-preserving norms are those in which contracting parties attempt to revolve disputes cooperatively among themselves and want to preserve their relationship. ${ }^{56}$ End-game norms, on the other hand, are usually incorporated in written contracts, where contracting parties no longer intend to continue a contractual relationship and want a neutral third party adjudicator to resolve disputes. ${ }^{57}$ In paper-based transactions, end-game norms are supposed to be legally enforceable contractual rights and obligations under the end-game dispute resolution, whereas relationshippreserving norms are usually self-enforcing (legally unenforceable) informal norms under the cooperative stage..$^{58}$

54 For example, commercial letters of credit have bilateral incentive mechanisms. Issuance of a letter of credit by an opening bank is not only a reputational bonding signal that the seller can rely on the credibility of the buyer's payment commitment, but also a signal that the seller will not default on its delivery obligation. Under transactions using letters of credit, the parties choose a formal condition stricter than they plan to enforce in practice so that the costs of formal compliance--together with the buyer's discretion to refuse payment when the formal conditions are not met-reinforce the seller's incentives to perform substantively. See Ronald J. Mann, The Role of Letters of Credit in Payment Transactions, 98 MICH. L. REV. 2494 (2000); Katz, Bilateral Assurance, supra note 11.

55 See Bernstein, supra note 31, at 1796.

56 See id. at 1796. There are two types of relationship-preserving norms. Performance norms "reflect the implicit extralegal terms transactors have agreed to abide by as long as they continue to trust one another and/or value potential future dealings." Id. Dispute-resolution norms are "norms that transactors follow in attempting to cooperatively resolve disputes in a manner that will not jeopardize future dealings." Id.

57 See id. End-game norms also have two types. The first type is "an absolute end-game where the parties, perhaps because of the action giving rise to the alleged breach, have decided not to deal with one another again." Id. The second type is "an end-game round, a situation where the parties are in a long-term contractual relationship that they wish to maintain, but where one or both of them have committed to following a strategy that binds them to seek application of [end-game norms] under certain circumstances." Id. at 1796-97.

58 See id. In this context, Bernstein argued in a series of her articles that sellers and buyers who deal regularly in a particular market prefer a formalistic approach in contract interpretation and thus do not necessarily want relationship-preserving norms (informal norms) to be used to resolve end-game dispute. While courts routinely take relation-preserving norms (informal norms) into account in resolving end-game dispute by applying the Uniform Commercial Code's usage of trade, course of dealing, and course of performance provisions, contractual formalists criticize the Uniform Commercial Code's contextual approach. They argue that applying relationship-preserving norms (informal norms) in end-game situations will prevent transactors from developing their own arrangements for dealing with the underlying transactions. 
However, the situation surrounding electronic commerce is unique. As previously discussed, due to both high ex ante and high ex post costs caused by the Internet's long-distance, low-value, and stranger-to-stranger nature, electronic commerce exists where formal legal enforcement is relatively difficult. Contracting parties in electronic commerce often have little chance to enforce contracts even though counter-parties breach the contract. In order to solve these problems, contracting parties often exchange bonds or hostages that encourage each other to perform contract obligations substantively. However, even if contracting parties exchange bonds, the exchange has little means of collecting from the other party when a party actually encounters poor contractual performance at the ex post enforcement stage. Thus, the most successful business models in electronic commerce are those with a much stronger incentive. The incentive creates not only a "complement" to legal enforcement, as is usually seen in a cooperative stage of a transaction mainly for purposes of settling a dispute voluntarily and amicably, but also a "substitute" for legal enforcement, as is usually seen in a transaction's end-game stage, mainly to enable the claimant to recover losses through judgment of a neutral adjudicator.

Incentive mechanisms are not an alternative between the above two, but these two levels of incentives co-exist. ${ }^{59}$ Contracting parties who rely solely on stronger end-game informal norms make their relationship unstable. In general, end game dispute resolutions are often time consuming, even if they informally take place online. For instance, the Buyer Protection Program implemented by Yahoo! Shopping that offers a buyer an opportunity to settle disputes with a Yahoo! merchant requires the buyer to formally file a complaint to Yahoo! Shopping within sixty days of purchase, and it takes a maximum of forty-five days for the buyer to receive a final decision. ${ }^{60}$ Even a typical end game mechanism like credit card chargeback systems, for another example, requires a formal process to assert claims against a credit card issuer, although the procedure is minimal. ${ }^{61}$ Thus, a party who is keen to secure substantive contract performance of its counterpart desires not only a relatively weaker mechanism that mainly functions in a cooperative stage, but also a stronger end game self-enforcing mechanism. In essence, typical incentive types of business models created two stages of incentive mechanisms using reputation and intermediation, namely the relationship-preserving stage and the end-game stage.

59 Indeed, the contracts that are observed in commercial transactions are neither perfectly contingent nor entirely relational. See Goetz \& Scott, supra note 12, at 1091.

60 See infra Part III.C.1.

61 See infra Part III.B.1. 
Further, the Internet's unique nature also raised another problem: since requiring additional offline procedures in dispute resolution often ruins the benefit of electronic commerce, a more desirable result is for the alternative dispute resolution mechanism to be completed solely in the online process. When business models try to incorporate an end-game dispute resolution mechanism in their online procedure, the models must rely on the multiple functions of the online intermediary. For instance, in a typical cyber shopping mall such as Yahoo! Shopping, an operator of the shopping mall may function as both a provider of cyber space to tenant online shoppers, and an adjudicator to settle disputes among buyers and the online shopper. ${ }^{62}$ Credit card issuers also function as both a provider of credit and an adjudicator through their chargeback system. ${ }^{63}$ An online auction site is another example of an auction site owner or its online payment service provider functioning as both service provider and adjudicator. ${ }^{64}$

Multiple functions of the online intermediary further make the nature of the online dispute resolution process unique. If the dispute must be resolved by the intermediary within its online procedure, the intermediary's own interests must also be considered. To this effect, agreed contract terms between contracting parties may not directly apply. For instance, credit card issuers may have conflicts of interest with the dispute between an auction seller and a buyer because card issuers have a claim against a buyer. Because the card issuer has a conflict of interest with the claimant and the respondent, the card issuer's judgment as an adjudicator is heavily influenced by how it protects its rights and claims. The dispute resolution is an informal out-ofcourt process where a third party adjudicator having conflicts of interest with claimants and respondents settles the dispute by applying informal end-game norms that are heavily influenced by the adjudicator's own interests rather than formal contractual terms.

Consequently, business models in electronic commerce uniquely offer two types of informal norms. For the first informal stage (informal relationship-preserving stage), a reputational bond, often complemented by a riskabsorbing function of a third party intermediary, creates an informal norm. This norm mainly works at a cooperative phase. In this first stage, a seller uses the buyer's reputation, obtained both online and offline, to verify information asserted by the buyer. When a dispute arises, both sellers and buyers try to reach a compromise for fear of the informal sanction of reputational damage. For the second informal stage, or the informal endgame stage, business models of electronic commerce create a mechanism of 
dispute resolution by a third party intermediary. When a dispute arises, contracting parties ask the third party intermediary to resolve the dispute. The third party adjudicator, usually a financial intermediary, often applies his own informal rules for dispute resolution rather than the contract terms.

\section{NORMATIVE IMPLICATIONS}

The self-enforcement system within electronic commerce business models, which primarily consists of a cooperative stage and an end-game stage, works effectively through the process of contract formation and performance, but does not finally bind contracting parties due to the system's "informal" nature. A party who does not accept the decision made by a third party intermediary will finally go to courts to receive legally enforceable judgment on the issues (formal end-game stage). In this very last end-game stage, courts apply the terms of contracts to resolve the dispute. Legal enforcement is especially important when a dispute arises out of issues that informal norms do not protect.

Understanding efficient allocation of informal and formal norms in electronic commerce may justify the court's formalistic enforcement of the standard terms of electronic commerce contracts. Two distinct reasons are suggested by the discussion in Part II. First, judicial intervention in electronic commerce will destroy the subtle balance between formal and informal norms and thus make electronic commerce inefficient. As long as website commerce operators develop a transactional scheme adopting a business model with efficient bonding mechanisms and informal norms, courts should be willing to consider the standard terms of electronic contracts as one of the factors for the efficient allocation of formal and informal norms. Second, it is assumed that reasonable consumers rationally select the regime of online contracts rather than offline paper based contracts. While paper-based face-to-face transactions may provide consumers with a cash-on-delivery equivalent condition as well as an opportunity for direct inspection of the quality and functionality of the product, the consumer abandons such opportunity and minimizes administrative costs by transacting through the Internet. Moreover, once consumers access a website and perceive the structure of electronic commerce, they may easily grasp the total mechanism of incentives in the business model. It is reasonable, therefore, to assume that rational consumers, who acknowledge the overall structure of incentives in the business model, often do not read standard terms not because the transaction is made online, but because they feel they are protected by informal norms. They will think that an online merchant's business model provides sufficient consumer protection.

Accordingly, courts, in deciding whether they should intervene in the standard terms within a disputed transaction, should be more sensitive to a 
business model that a merchant adopted for its online transactions. As long as the underlying business models are efficiently allocating legal and nonlegal norms, the more formalistic interpretation of contract terms has great appeal. This does not mean that courts should no longer be concerned about consumers unwillingly entering into standard terms of agreements that are fundamentally exploitative and unilaterally beneficial to the merchant. Analyzing the business model that underlies an electronic commerce transaction gives courts a standard by which they determine their level of sensitivity to such consumer exploitation.

Electronic commerce is so standardized and automated that understanding the total mechanism of a business model is important. A transaction in an electronic commerce business model is created in a conveyer-belt style of machine-made, automated contract-formation process, where "electronic agents" are actually engaged in negotiating with consumers. ${ }^{65}$ Electronic commerce operators' intent is incorporated in the design of the business model. In this sense, the level of sensitivity to consumer exploitation may be dependent on the business model's structure. The sensitivity to consumer protection differs according to how much the subject of the dispute is protected or exploited by the business model's incentive mechanisms. If a subject matter is covered by an efficient informal end-game dispute resolution mechanism within the merchant's business model, courts should interpret these terms in accordance with their formal meaning. If the subject is not covered by the business model's informal dispute resolution mechanism, or if the business model's incentive mechanism that covers the subject does not efficiently allocate legal and non-legal norms, it tends to be more suspicious of exploitation.

For example, Specht v. Netscape Communications ${ }^{66}$ involved subject matter outside the scope of an incentive mechanism. In Specht, the plaintiff argued that using SmartDownload, Netscape's free of charge software, had transmitted private information about the user's file transfer activity on the Internet, thereby creating an electronic surveillance of the user's activity in violation of the Electronic Communications Privacy Act and the Computer Fraud and Abuse Act. ${ }^{67}$ The New York federal district court held that the language labeled at the hyperlink "Please review and agree..." constituted a mere invitation to the terms and conditions, thereby denying the enforce-

65 For a discussion of machine-made contract and electronic agents, see Margaret Jane Radin, Human, Computers, and Binding Commitment, 75 IND. L. J. 1125, 1130 (1999), in which Radin notes that "[i] $\mathbf{n}$ this category of machine-made contract, the idea is that two computers (rather than two humans, or one human and one computer) 'negotiate' with each other and arrive at 'agreement' with each other." 
ability of an arbitration clause in the boilerplate terms. ${ }^{68}$ However, the essence of this case was that consumer privacy was not within the scope of the protection by informal norms in the business model's incentives. From the business model's perspective, the incentive mechanism in downloading SmartDownload was exchanging a free download for the user's compliance with the hyperlinked terms and conditions. Because consumer privacy may not generally be considered the subject of bargaining in online transactions, the court's suspicion of consumer exploitation was justified.

On the other hand, the case of ProCD $v$. Zeidenberg ${ }^{69}$ involved a transaction dispute within the range of a business model's incentive mechanism. On the condition that he might return the disk for refund if he did not agree to the terms displayed by the disk, defendant Zeidenberg purchased a disk containing a database produced by ProCD. ProCD claimed that the defendant violated a prohibition against reselling the data, which had been provided in the displayed terms. ${ }^{70}$ Although the defendant argued that the prohibition did not constitute an enforceable agreement because the terms were displayed after he purchased the disk, the court held that the contract had been formed as long as the defendant had an opportunity to read the terms and agreed to them. ${ }^{71}$ While this conclusion by itself may be upheld, the more essential point is to what extent ProCD accepted a refund in its regular transaction practice as a business model designed by it. As a restriction of sublicense may be an essential part of the rights that a licenser should protect, dispute concerning a sublicense restriction shall be covered by a business model's informal dispute resolution mechanism. Precise understanding of the overall business model may be essential when courts look to the transactional substance. In ProCD, the actual measure taken by ProCD for implementing its refund policy was key to understanding the transactional substance.

To summarize, because electronic commerce is more automated and standardized than paper-based transactions, contract term interpretation must be made by considering the overall business model and its embedded incentive mechanisms that support informal self-enforcement. In general, prevailing electronic commerce adopts efficient mechanisms of self-enforcement. It allocates formal and informal regimes so well that relatively formalistic interpretation of contract terms (whether those terms are browsewrapped or clickwrapped in a website screen) are generally justified as an interpretation principle. This does not mean that courts should not consider

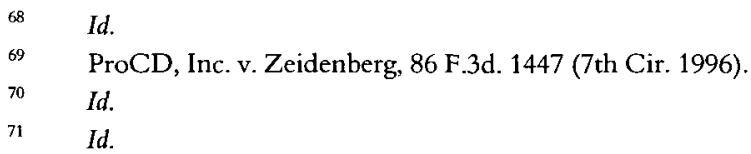


consumer exploitation, Internet fraud, or other failure of efficient allocation of costs and benefits arising from the novelty of electronic commerce. Although courts are likely to emphasize an aspect of contract formation procedure, where accessibility to those online terms and adequate notice are especially questioned, such requirements of accessibility and adequate notice do not necessarily give equitable solutions to each dispute. While, as is seen in Specht, courts often express skepticism against browsewrap contracts, the reality is that many businesses using browsewrap employ even less satisfactory notices than in Specht. ${ }^{72}$ This article therefore suggests that when such issues concerning consumer protection are argued, courts must at least be sensitive to overall efficiency underlying the merchant's business model in interpreting contract terms.

\section{EMPIRICAL ANALYSIS}

This article assumes that electronic commerce possesses two distinct business models according to which costs, ex ante or ex post, are emphasized as a cost-reduction target. Since contract drafting is costly and electronic commerce cannot be a tool for reducing the drafting costs, most business models are obliged to place a cost reduction target on establishing a system of self-enforcement. Business models and private contracting are assumed to be closely related because contracting parties' choice of complete or incomplete contracts influence a formation of business models; the form of the contract reflects the incentive mechanisms to be incorporated in the business model. Based on these assumptions, Part III examines currently prevailing business models of electronic commerce and explains how the above mechanisms work in each model.

For this analysis, electronic commerce shall be classified into three different types based on the number of players. Transactions are classified according to the strength of the reputation as a bond. The first type is a oneto-one transaction, where two particular parties are supposed to enter into transactions from the outset. In many cases, the two particular parties have already verified each other's reputation by using offline information, and thus they do not need an additional incentive online.

The second type of transaction, one-to-many, includes the situation where one particular party (a site operator) that runs an electronic commerce operation enters into transactions with multiple counter-parties. Usually, in this case, one party's credibility (the site operator's reputation) has already 
been verified before the multiple counter-parties go online, but the site operators have not verified each counter-party's credibility. This situation is commonly seen in online shopping sites operated by highly reputed business entities. When consumers go to a site, they already know through offline information that the online shop owner's reputation is so esteemed that they may enter into a transactional relationship with the shop owner without a fear of transactional difficulties.

The third type, a many-to-many transaction, refers to situations where two unknown parties from among multiple candidate-players are supposed to enter into transactions. In many-to-many transactions, both parties have yet to verify each other's reputation. Thus, they need a bilateral incentive online more intensively in this type than in one-to-many transactions. This type is found particularly in the e-marketplaces or auction sites where most transactions are between strangers.

\section{A. One-to-One Transactions ${ }^{73}$}

\section{Traditional EDI (VAN-EDI)-OFfline PAPER Contracts}

Traditional electronic data interchange ("EDI") is a typical illustration of a one-to-one transaction. Technically, the term EDI refers to a general group of electronic business languages, such as ANSI X12 or UN/EDIFACT. ${ }^{74}$

73 This classification is compatible with new terminology invented in a marketing study, the "one-to-one marketing" strategy. The one-to-one marketing is a strategy that places its marketing target on an individual customer rather than mass consumers. This classification requires extensive, repeated, and recorded communications with customers as well as a company's ability to store, analyze, and process the customer data. The Internet business is often compatible with one-to-one marketing because the strategy enables businesses to store individual information effectively at lower costs. One-to-one marketing strategies were designed to contrast with traditional mass marketing where manufacturers first produce standard products and then look for anonymous customers. While mass marketing strategies have their target on multiple consumers, one-to-one marketing strategies focus on an individual customer and develop a tailored product that is suitable for the individual customer. There are four important steps to ensure that one-to-one marketing will work effectively: (i) identifying customers, (ii) differentiating among them, (iii) interacting with them, and finally, (iv) customizing products or services to fit each individual customer's needs. In this respect, the information verification is required especially in the first step of the above four. A verification process occurs when a business finds one counter-part (one-to-one stage) from among multiple candidates (one-to-many or many-to-many stage). In this respect, successful business models can efficiently transform players in one-to-many or many-to-many transactions into those in the one-to-one equivalent contract relationship. This transformation process is a starting point for marketing development. The terminology of the one-to-one marketing strategy is an invention of Don Peppers and Martha Rogers. See Don Peppers, Martha Rogers, and Bob Dorf, Is Your Company Ready for One-to-One Marketing?, HaRV. Bus. Rev. Jan. - Feb. 1999, at 151 [hereinafter Peppers \& Dorf]. See also Peppers \& Rogers Group Website, at http://www.1to1.com (last visited Oct. 15, 2004).

${ }_{74}$ See ASC X12 Website, ASC X12 Homepage, at http://www.x12.org/x12org/index.cfm (last 
Traditionally, EDI involved an online data transfer between two communication end points connected by a Value Added Network (VAN). In a typical sales transaction, a seller and a buyer deploy a server that acts as an end point gateway for EDI communications. However, there have been traditional barriers to implement a VAN due to high costs. VAN-EDI needs a data transformation system and proprietary software in each client so that the client may be able to use the data in the base system. Further, substantial labor and costs are required for maintenance and frequent system upgrade. Therefore, generally only major companies that meet large cost and trading volume requirements have used traditional VAN-EDI. EDI is a substitute for conventional paper documents in business. The computer communicates any data electronically in standardized formats, such as purchase orders, invoices, shipping notices, and remittance advices. ${ }^{75}$ Before Internet transactions exploded in the late 1990's, typical electronic commerce was an EDI of closed networks, used only among the limited relational parties. ${ }^{76}$ The EDI process is supported by the mutual dependence on long-term transactions. Contracting parties' investments in the EDI itself are relationalspecific investments, which enhance each other's compliance with a longterm contract. ${ }^{77}$

At the same time, a discussion on how to assure the validity and predictability of commercial transactions in the use of EDI continued. In 1989, a Task Force created by the subcommittee of the American Bar Association's Committee on the Uniform Commercial Code implemented the Model Electronic Data Interchange Trading Partner Agreement and

visited Oct. 15, 2004). ANSI X12 (ANSI Accredited Standards Committee X12) is produced by the Accredited Standard Committee X12 (ASC X12). In 1979, the American National Standards Institute (ANSI) chartered the Accredited Standards Committee (ASC) X12 to develop uniform standards for EDI. See ASCX12 Website, The Creation of ASC X12, at http://www.x12.org/x12org/about/X12History.cfm (last visited Feb.15, 2005). UN/EDIFACT (United Nations' rules for Electronic Data Interchange for Administration, Commerce, and Transport) is a set of standards, directories, and guidelines for the electronic interchange of structured data, which is recommended within the framework of the United Nations. UN/EDIFACT is approved and published by the UN/ECE (United Nations Economic Commission of Europe) in the United Nations Trade Data Interchange Directory (UNTDID) and is maintained under agreed procedures. See UNECE UN/EDIFACT Website, UNECE UN/EDIFACT Main Page, at http://www.unece.org/trade/untdid/welcome.html (last visited Oct. 15, 2004).

75 Electronic Messaging Services Task Force, The Commercial Use of Electronic Data Interchange A Report, 45 Bus. LAW. 1645, 1649 (1990) [hereinafter The Commercial Use of Electronic Data Interchange]; Electronic Messaging Services Task Force, Model Electronic Date Interchange Trading Partner Agreement and Commentar, 45 BUS. LAW. 1717, 1718 (1990).

76 Jean Braucher, Rent-Seeking and Risk-Fixing in the New Statutory Law of Electronic Commerce: Difficulties in Moving Consumer Protection Online, 2001 WIS. L. REV. 527, 534 (2001).

$\pi \quad$ See Williamson, Transaction-Cost Economics, supra note 11 (regarding the relation-specific investment). 
Commentary ("Model EDI Agreement"). ${ }^{78}$ The Task Force's primary intent was to "be self-sufficient as a tool for attorneys asked to prepare definitive agreements governing the use of EDI in commercial transactions." 79 The Task Force observed that EDI is implemented most frequently by transactors with a long-standing purchase and sale relationship. ${ }^{80}$ The Model EDI Agreement does not presuppose stranger-to-stranger contracts among multiple parties. The business models targeted by the Model Agreement are typical two party relation-specific investments against the EDI facilities. Their primary purpose is to minimize various administration costs and enhance self-enforcement by having EDI assets as relation-specific hostages. Because EDI transactions presuppose that two relational parties engage in similar transactions regularly with intent to preserve their relationship, contracting parties may write a paper contract offline at cheaper costs prior to proceeding with individual transactions online.

\section{INTERNET-EDI-FROM PAPER TO ONLINE CONTRACTS}

The advent of Internet technology enables EDI to be developed in an open network. TCP/IP network makes technical connections between inhouse and EDI systems easier. Any company can participate in EDI simply by using a Web-browser or mail software, and thus communication and technical costs are substantially lower than traditional VAN-EDI. The advent of Internet-EDI enables online contract drafting costs to be much lower.

While Internet-EDI has an advantage in utilizing the Internet open network, the transformation of EDI data into each in-house system's unique data format poses a technical difficulty. ${ }^{81}$ As a tool to solve this connection

78 The Commercial Use of Electronic Data Interchange, supra note 75, at 1651-53.

$79 \quad$ Id. at 1653 .

8n Id. The Task Force set an example of the process of EDI as follows:

$A B C$ and $X Y Z$ have a long-standing purchase and sale relationship. Recognizing the economic and administrative benefits attributed to $E D I, A B C$ announces to its vendors, including $X Y Z$, that $\mathrm{ABC}$ will require, or provide incentives for, the use of $\mathrm{EDI}$ in future transactions. $\mathrm{ABC}$ engages a third party service provider (referred to in the Model Agreement as a "Provider") to receive, transmit, and sort the various $\mathrm{EDI}$ transmissions of $\mathrm{ABC}$. In addition, $\mathrm{ABC}$ determines which paper-based documents will be replaced by EDI formats, as well as which industry standards will be adopted around which all transmissions will be structured, and implements certain security procedures for assuring the authenticity and integrity of the electronic communications. All of this information is communicated to ABC's vendors, one of which is $X Y Z$, who must implement EDI accordingly to keep ABC's business (or obtain the available incentives, as the case may be).

Id. at 1655-56.

81 See, e.g., Electronic Commerce Promotion Council of Japan, Intemet EDI (XML/EDI) Introduction Guide Book (2003), http://www.ecom.jp/ecom_e/press/20030529/InternetEDIGuidebook.pdf (last visited Dec. 21, 2004). 
problem, XML-EDI recently has attracted great attention. Extensible Markup Language (XML) is a universal markup language being developed by a working group of the World Wide Web Consortium (W3C). ${ }^{82} \mathrm{XML}$ provides a file format for representing data, a schema for describing data structure, and a mechanism for extending and annotating various types of data with semantic information. ${ }^{83}$ XML allows developers to easily describe and deliver rich and structured data in a standard and consistent way. Developers can also transform XML into many other types of data, such as HTML, CSV, and CDF, so that they can view the data in a browser. Unlike HTML that displays text and images now found on Web pages, XML enables the exchange of structured data over the Web. ${ }^{84}$ Developing cross-industry XML specifications requires a uniform standardization such as (i) exchanging transactional data, (ii) developing messaging and protocol infrastructure, (iii) creating code-value dictionaries, (iv) devising trading partner agreements, and (v) defining business processes performed in conjunction with businessto-business exchanges. ${ }^{85}$ XML-EDI may shift contract practice in EDI transactions from the traditional paper regime to the online one, as if the online process were a paper exchange by hand delivery, fax, or telex. However, XML-EDI still has a long way to go before it becomes universal. Research in Japan shows that only $2.5 \%$ of Japanese firms have implemented XML-EDI, and $4.6 \%$ of firms are currently preparing to use it. ${ }^{86}$

82 See World Wide Web Consortium Website, World Wide Web Consontium Homepage, at http://www.w3.org (last visited Dec. 21, 2004).

83 For the general explanation of XML, see, for example, W3 Schools Website, XML Tutorial, at http://www.w3schools.com/xml/default.asp (last visited October 18, 2004); ASC X12 Website, Frequently Asked Questions (FAQs), at http://www.x12.org/x12org/about/faqs.cfm\#b1 (last visited Oct. 15, 2004); Electronic Commerce Promotion Council of Japan (ECOM) Homepage, Topics, at http://www.ecom.jp/ecom_e/index.html, (last visited Oct. 15, 2004); Xenos Website, Homepage, at http://www.xmlglobal.com/homepage.asp (last visited Oct. 15, 2004). See also Jane Kaufman Winn, Making XML Pay: Revising Existing Electronic Payments Law to Accommodate Innovation, 53 SMU L. REV. 1477, 1494 (2000) (noting that XML might play a larger role in creating mechanisms of consumer electronic payments if regulators successfully intervene in standard-setting processes to incentivize industry's acting upon consumer preferences).

${ }^{84}$ See W3 School's Website, XML Tutorial, Introduction to XML, at http://www.w3schools.com/xml/xml_whatis.asp (last visited Oct. 18, 2004) (emphasizing that XML intended to describe data and focus on the data's content, whereas HTML intended to display data and focus on the data's looks).

${ }^{85}$ ASC X12 Website, Frequently Asked Questions (FAQs), at http://www.x12.org/x12org/about/faqs.cfm\#a2 (last visited Dec. 21, 2004).

86 Japan Electronic Data Interchange Council, Kokunai Kigyo Ni Okenu EDIJittai Chosa [Research on EDI in Japanese Domestic Company], (2000), at http://www.ecom.jp/jedic/activity/jittai2002.pdf (last visited Oct. 17, 2004). 


\section{SUMMARY}

The common example of a one-to-one transaction is an EDI platform that provides players with places to negotiate and contract. EDI originally started from a closed network between two parties who knew each other well (VAN-EDI), but the advent of the Internet made EDI open to multiple players (Internet-EDI). Traditional one-to-one transactions do not require any incentive online to strengthen substantive performance. Contracting parties have often verified information asserted by counter-parties by using an offline information source prior to beginning the negotiations. In addition, EDI investments, which constitute relation-specific investments, function as a hostage. These investments give transactors a strong incentive to perform contracts substantively and to continue transactions, at least until they recover their investment costs.

Traditional EDI does not presuppose online contracting in its EDI arrangement. As ex ante contract specification costs in traditional EDI are already lower offline due to their long-term relationship, ${ }^{87}$ contracting parties often write their contracts on an offline, paper basis. However, recent technological development made EDI possible in multilateral situations. Since Internet-EDI substantially reduces EDI related investment costs so that more transactors may enter into EDI systems more easily, the bar which transactors need to pass in order to join EDI has become lower. Further, XML-EDI enables contracting parties to conclude their contracts online. EDI systems are becoming much closer to being a mere substitute for the traditional information paper exchange by fax or telex, easing the online execution of contracts.

\section{B. One-to-Many Transactions}

\section{ONLINE SHOPPING SITES-BILATERAL INCENTIVES THROUGH Payment Mechanisms}

An online shop operated by a reputed business entity is a typical example of one-to-many electronic commerce transactions that use a credit card payment system. Unlike an auction site, players consist of one specific seller (an online shop owner) and multiple buyers. The transactional mechanism is simple: a consumer goes into an online shop to find goods that he or she is looking for. When the consumer finds the goods, he or she drags the

87 Indeed, Model EDI Agreement presupposes two parties with a long-standing purchase and sale relationship. Contract terms are negotiated and created based on past transactional experiences. See The Commercial Use of Electronic Data Interchange, supra note 75, at 1655-56. 
picture of the goods into a virtual basket. After the consumer selects the goods he or she wants, he or she settles payment with a credit card. The goods are delivered several days after the purchase. In these transactions, online shop owners usually minimize their risks by using credit card companies' authorization processes. For online shop owners, verifying a buyer's credibility is extremely important due to its anonymity. Accordingly, one of the most important conditions for successful online shops is to select reliable financial institutions that intermediate transactions and provide buyers with credit. By selecting a financial intermediary, an online shop owner may switch the target of their risk analysis from buyers to the financial institution.

On the other hand, consumers have to rely on offline soft information outside electronic commerce as long as they do not have other sufficient tools to evaluate online shop owners. Consumers are concerned about who is operating the online shop. In fact, consumers carefully choose highly reputed business entities when they proceed with electronic commerce. Before purchasing, most consumers have already verified the reliability of the online shop owner. Indeed, famous manufacturers or giant companies are often most successful in implementing electronic commerce businesses, such as the airline e-ticket used by airplane companies or computer sales by large manufacturers. These companies have already received outstanding reputations through their activities in real world transactions. Empirical facts show that successful online shopping operators such as Priceline.com and Amazon.com have spent a considerable amount of money in advertising fees to establish good brand images. ${ }^{88}$

However, even though highly reputed businesses operate online shopping sites, their reputations do not necessarily satisfy the verification requirement of contracting parties. Complete incentives in electronic commerce are those by which businesses can not only verify consumers, but also employ robust self-enforcement devices within business models as a substitute for formal enforcement. In online shopping sites, payment mechanisms offer these incentives. Indeed, businesses have introduced various payment systems into online shopping sites since the advent of Internet commerce.

Credit Card Payment: Credit card payment is the dominant payment mechanism in electronic commerce. ${ }^{89}$ The credit card system offers two

88 For example, eToys's advertisement expense in the last quarter of 2000 was $29.5 \%$ of its total sales in the same period, which exceeded its gross margin of $24.3 \%$. Fujitsu Research Institute Website, at http://www.fri.fujitsu.com/hypertext/fri/cyber/colum/click/new01.html (last visited Feb. 27, 2004).

${ }_{89} \quad J a n e$ Kaufman Winn, Clash of the Titans: Regulating the Competition Between Established and Emerging Payment Systems, 14 BERKELEy TECH. L. J. 675, 687 (1999) [hereinafter Winn, Clash of the Titans]; David E. Sorkin, Payment Methods for Consumer-to-Consumer Online Transactions, 35 AKRON L. Rev. 1, 7 (2001) [hereinafter Sorkin]. 
stages of incentives to online shipping sites. First, credit card issuers function as a financial intermediary for a transaction between the merchant and the consumer. The credit card system strikes a subtle balance of both their incentives with the intermediation of a card issuer. ${ }^{90}$ Intermediation by a card issuer functions as an undertaker of the buyer's non-payment risk, and at the same time works as a reputational intermediary, assuring the seller's fair dealing (informal relationship-preserving stage). A credit card system, through its chargeback mechanism, assures that the seller will not act opportunistically by taking advantage of the standard terms of contracts that do not necessarily reflect the substance of the transactions. Second, the mechanism of credit card payments does not offer "finality" at the time of credit card authorizations, but instead offers an informal dispute resolution mechanism. ${ }^{91}$ More concretely, credit card payments give a consumer the opportunity to receive a refund of his payment through the credit card's chargeback mechanism supported by regulations (informal end-game stage).

Regulation $\mathrm{Z}$, which regulates credit card transactions, provides cardholders with (i) the right to withhold "any portion of any required payment that cardholders believe is related to the disputed amount," to assert against card issuers "all claims (other than tort claims) and defenses arising out of the transaction and relating to the failure to resolve the dispute" with merchants. ${ }^{93}$ The right of cardholders to assert claims and defenses applies only if cardholders have made "a good faith attempt to resolve disputes with the person honoring the credit card." ${ }^{94}$ In addition, cardholders may assert claims only if the amount of credit exceeds $\$ 50$, and the disputed transaction occurred in the cardholder's home state or, if not within the home state, within 100 miles from the cardholder's address. ${ }^{95}$ Despite the above limitations, a card issuer often voluntarily accepts a chargeback even if the transaction does not qualify under the requirements of Regulation $Z{ }^{96}$

Regulation $\mathrm{Z}$ also provides a consumer with protection against the unauthorized use of his or her credit cards. "A cardholder shall be liable for unauthorized use of a credit card only if: (i) [t] he credit card is an accepted credit card;" (ii) "[ $t]$ he card issuer has provided adequate notice of the

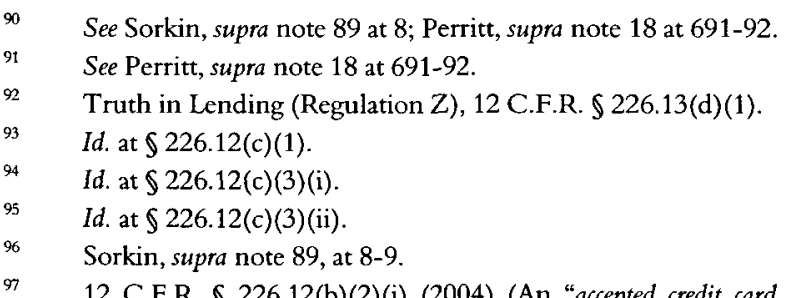

12 C.F.R. $\$ 226.12(\mathrm{~b})(2)(\mathrm{i})$ (2004) (An "actepted credit card means any credit card that a cardholder has requested or applied for and received, or has signed, used, or authorized another person to use to obtain credit.") (emphasis added). 
cardholder's maximum potential liability and of means by which the card issuer may be notified of loss or theft of the card;"98 and (iii) "[ $t$ ]he card issuer has provided a means to identify the cardholder on the account or the authorized user of the card." However, mail order or telephone order (MOTO) transactions - which include Internet credit card transactions-are card-not-present transactions, and do not satisfy the third requirement listed above. If card issuers cannot provide a means to identify cardholders in electronic commerce, "card issuers may not contest a cardholder's claim that a charge was not authorized, and under certain risk allocation rules, card issuers charge the transaction back to merchants." 100 For merchants to avoid chargeback, they must prove that they indeed provided goods or services to the cardholder.

Electronic Fund Transfer / Debit Card Transactions: The electronic fund transfer is a payment mechanism in which payment is made through the Automated Clearing House (ACH). Debit cards are those which debit payment automatically from a buyer's account at the time of purchase and credit a seller's account a few days after the purchase. ${ }^{101}$ Unlike credit cards, debit cards automate fund removal from bank accounts and do not require cardholders to pay bills. Although the use of debit cards is growing rapidly in the United States in real world transactions, debit cards have not attained popularity in online transactions. ${ }^{102}$

98 Id. at $\$ 226.12$ (b)(2)(ii) (stating that "the notice shall state that the cardholder's liability shall not exceed $\$ 50$.").

99 Id. at $\ 226.12(\mathrm{~b})(2)(\mathrm{iii})$. The Credit Billing Act provides for a creditor's obligation to investigate an obligor's claims of billing errors. After receiving a notice of billing errors from an obligor, a creditor shall either make appropriate corrections in the account of the obligor, or send a written explanation or clarification to the obligor, after having conducted an investigation describing the reasons why the creditor believes the billing is correct. Under the Credit Billing Act, the billing errors include "A reflection on a statement of goods or services not accepted by the obligor or his designee or not delivered to the obligor or his designee in accordance with the agreement made at the time of a transaction." 15 U.S.C. $\$ 1666(\mathrm{~b})(3)$ (2003). See also, Perritt, supra note 18, at 689.

${ }_{100}$ Winn, Clash of the Titans, supra note 89, at 687 . In this connection, Japanese law does not have such a rule that card issuers bear the risk of unauthorized transactions. However, in practice, Japanese card issuers retain the risk of unauthorized transactions, covering such risk by insurance or, when insurance does not cover, bearing the risk by itself. See Ronald J. Mann, Credit Card and Debit Card in the United States and Japan, 55 VAND. L. REv. 1055, 1089-90 (2002) [hereinafter Mann, Credit Card and Debit Card in the United States and Japan].

101 See Mann, Credit Card and Debit Card in the United States and Japan, supra note 100, at n.2.

102 A survey reports that in 2000 there were 8.3 billion dollars of debit card purchase transactions in the United States, a $30 \%$ increase from the previous year. Id. at 1056 n.3. On the other hand, debit cards are not popular in Japan. In December 2000, consumers used the Japanese debit card system, or the J-Debit card, for slightly over 500,000 transactions. This accounted for less than $1 \%$ of all card-based transactions. Id. at 1100 . 
Both electronic fund transfers and debit card transactions are regulated by Regulation E, which implements the Electronic Transfer Act. ${ }^{103}$ Compared with Regulation Z, however, Regulation E provides narrower protection to cardholders. First, while Regulation $Z$ gives cardholders the right to withhold payment on the amount in dispute, ${ }^{104}$ Regulation $E$ does not have any dispute resolution mechanism for post-payment disputes. This means that neither electronic fund transfers nor the debit card system gives buyers any assurances that the seller will respond in good faith to the buyer's claim to the related sales transactions. Secondly, although Regulation E limits liability of a debit cardholder for unauthorized transactions up to $\$ 500$, timely notice is strictly enforced in order for the cardholder to enjoy the limitation of liability. ${ }^{105}$ Because of public pressure, some debit card issuers have waived the benefit of a low level of consumer protection by allowing consumers to limit liability for unauthorized transactions to the same $\$ 50$ that applies to credit cards without a timely notice requirement. ${ }^{106}$ Nevertheless, such treatment does not necessarily give buyers perfect assurance. The "finality" of payment, a fundamental nature of debit card and electronic transfers, deprives consumers of the opportunity for an informal end-game dispute dissolution when the dispute arises out of imperfect performance by a merchant.

Electronic Money: Electronic money or digital cash is a new payment system that stores and transfers value ("e-cash") online. ${ }^{107}$ An individual who desires to use e-cash to make a purchase via the Internet could download ecash (taken from his bank account) to his wallet, which is on his personal

103 The Electronic Fund Transfer Act provides a basic framework regarding "the rights, liabilities, and responsibilities of participants in electronic fund transfer systems." 15 U.S.C. $\$ 1693$ (2004). The Federal Reserve Board has an authority to implement regulations that regulate the fund transfer system, such as the automated teller machine (ATM), the point-of-sale terminal (POS), the automated clearinghouse $(\mathrm{ACH})$, the telephone bill-payment system, or the home banking program. See Electronic Fund Transfer (Regulation E), 12 C.F.R. $\$ 205.16$.

104 Truth in Lending (Regulation Z), 12 C.F.R. $\$ 226.12(\mathrm{c})(1)$.

105 Electronic Fund Transfer (Regulation E), states, in part, that:

If the consumer fails to notify the financial institution within two business days after learning of the loss or theft of the access device, the consumer's liability shall not exceed the lesser of $\$ 500$ or the sum of:

(i) $\$ 50$ or the amount of unauthorized transfers that occur within the two business days, whichever is less; and

(ii) The amount of unauthorized transfers that occur after the close of two business days and before notice to the institution, provided the institution establishes that these transfers would not have occurred had the consumer notified the institution within that two-day period.

Id. at $\$ 205.6$.

${ }_{106}$ Winn, Clash of the Titans, supra note 89, at 689.

107 See id. at 691-93 (describing electronic money). 
computer hard drive. ${ }^{108}$ The software used with this program then deducts e-cash from the wallet when an individual purchases an item from a merchant. ${ }^{109}$ After the merchant requests to transfer the e-cash back to a bank, the bank will "cancel the [e-cash] and credit the merchant's account with the bank." 110 Electronic money offers finality of settlement in that the payment may no longer be revoked once e-cash is transferred.

Despite many attempts in the late 1990's, most of the digital cash services did not attract consumers. ${ }^{111}$ Presumably, these digital cash systems did not achieve popularity because their business models offered few incentives. First, the incentive mechanism functioned unilaterally to the benefit of sellers. The digital cash system offered no specific incentive for sellers to verify a buyer's credibility. Secondly, the intermediation of the digital cash issuer offered a substantial risk reduction only if the digital cash issuer was well-reputed. However, due to the system's brief history, the offline reputation of the digital cash issuer was often not high enough to function as a bond, as opposed to the credit card companies whose long histories provided sound reputational bonds.

Secure Electronic Transaction (SET) / Secure Sockets Layer (SSL): The SET is an open technical standard for the commerce industry developed by Visa and MasterCard as a way to facilitate secure payment card transactions over the Internet. The SET protocol consists of four components: the Cardholder Application, or the Wallet, which is run by an online consumer and enables secure credit card payment over a network; the Merchant Server, which is run by an on-line merchant to process credit card payment and authorizations; the Payment Gateway, which is run by an acquirer or a designated third party that processes payment-related information and interfaces with private financial networks; and finally the Certificate Authority component, which is operated by a financial institution or an approved third party who is authorized to issue and verify digital certificates. ${ }^{12}$ SET uses cryptography to "provide confidentiality of information", "ensure payment integrity", "authenticate both merchants and cardholders", and "make payment processing on the [Inter]Net faster, safer, and more secure." ${ }^{113}$ Cryptography

Id. at 692 .

Id.

Id.

11 See Sorkin, supra note 89 , at 9 . The pioneer of digital cash, DigiCash, attempted to exploit the market of online electronic money, but declared Chapter Eleven in 1998 and discontinued service in the United States. Other electronic payment technologies, such as MilliCent and CyberCoin, have had little success thus far in obtaining demand for their products. Winn, Clash of the Titans, supra note 89, at 692-93.

112 See, e.g., William Stallings, Introduction To Secure Electronic Transaction (SET), available at http://www.informit.com/articles/article.asp?p=26857 (2002).

113 IBM Website, Cryptography and SET Part I, at http://www-3.ibm.com/software/genservers/ 
mainly benefits the merchants, since the SET protocol provides the merchants with the mechanism to verify that buyers are those who they claim to be. However, even though SET is "a very sophisticated system for improving the security of electronic funds transfers over open networks," SET did not attain popularity from the outset and "by early 1999 was no longer in the forefront of discussions about Internet commerce security." 114

On the other hand, the Secure Sockets Layer (SSL), invented by Netscape, is a simpler protocol for securing Internet transactions. ${ }^{115}$ The protocol uses a digital certificate to identify merchants' servers, but does not use a digital signature. ${ }^{116}$ The certificate only verifies consumers' browsers, not the consumers themselves. ${ }^{177}$ The consumers' browsers "validate the server's certificate, and then uses the public key in the certificate to share a symmetric key with the server ... [T] he shared symmetric key is used to encrypt communications between the browser and the server, preventing credit card or other sensitive information from being sent over the Internet." ${ }^{118}$ However, even though SSL is widely used for security purposes, SSL is not completely a bilateral incentive, because the protocol does not give contracting parties an incentive for fair contract performance.

If SET is more secure than SSL, why has SSL achieved widespread acceptance in the field of electronic commerce? Comparing the function of both protocols, SET additionally offers the assurance that a particular consumer is exactly the person who is attempting to deal with the merchant. Nevertheless, there is no significant difference on the side of consumers. SET does not offer any effective incentive structure for consumers despite SET's lengthy and complicated mechanism. Consumers actually desire to have some additional assurance mechanisms to verify site owners whose reputation does not perfectly work as a bond.

\section{Electronic Tender Procurement Systems - Government REPUTATION}

Electronic tender procurement systems presuppose the existence of one particular purchaser and multiple sellers or seller-candidates. Under this system, seller-candidates post bids in a procurement auction, and those

commerce/payment/part1.html (last visited Oct. 24, 2004).

114 Winn, Clash of the Titans, supra note 89, at 690.

115 See Netscape Website, Secure Sockets Layer, at http://wp.netscape.com/security/techbriefs/ssl.html (last visited Oct. 24, 2004).

116 Winn, Clash of the Titans, supra note 89, at 696.

117 Id.

$118 \quad$ Id. 
sellers that posted the lowest price are entitled to start contract negotiations with the purchaser. The most suitable purchasers under electronic tender systems are government agencies. Many government agencies have attempted to introduce new electronic tender systems for government procurements. In Australia, the Commonwealth Government has implemented the Australian Government Tender System (AusTender), which enables bidders to access the selected Commonwealth Government bidding opportunities electronically. ${ }^{19}$ In Hong Kong, the Government Supplies Department (GSD) uses the Electronic Tendering System for the procurements of all government departments and some non-government bodies. ${ }^{120}$ In Singapore, the Singapore Government Electronic Business Partner (GeBIZ Partner) is a central website for the public to participate in government procurement activities. ${ }^{121}$ In Japan, the Ministry of Public Management, Home Affairs, Posts and Telecommunications, has started to operate the Electronic Tender and Examine System for making government procurement processes electronically. ${ }^{122}$ It appears that electronic tender systems generally aim to reduce administrative costs. Unlike online shopping site owners, government offices operating electronic tender systems probably have stronger reputations so that bidders will be able to enter into electronic tender processes without requesting any additional incentive mechanism.

The United States is no exception. Both federal and state agencies have made many attempts to create electronic procurement systems. For federal agencies, the U.S. General Service Administration established GSA Advantage!, the online shopping and ordering system that provides access to thousands of contractors and millions of services and products. ${ }^{123}$ One component of GSA Advantage! is e-Buy. e-Buy is an electronic system designed to allow government agencies (Federal Buyers) to obtain a quotation or proposal directly on-line for a wide-range of services and products

119 See AusTender Website, Homepage, at http://www.tenders.gov.au (last visited Oct. 24, 2004). AusTender is the initiative of the Commonwealth Electronic Procurement Implementation Strategy by the National Office for the Information Economy. AusTender refers to any business opportunity advertised by Australian Government agencies. States and territories of Australia have their own electronic tender systems. See, e.g., http://www.cpsc.nsw.gov.au/e-procurement (last visited Feb. 28, 2005) (New South Wales); http://notes.nt.gov.au/Tender.nsf (last visited Feb. 28, 2005) (Northern Territory); http://www.gem.wa.gov.au/ (last visited Feb. 28, 2005) (West Australia).

${ }_{120}$ See Electronic Tender System Website, Homepage, at https://www.ets.com.hk/English/ GeneralInfo/info.asp (last visited Oct. 24, 2004).

121 See GeBiz Partner Website, Homepage, at http://www.gebiz.gov.sg (last visited Oct. 24, 2004).

122 See Ministry of Public Management, Home Affairs, Posts and Telecommunications, Electronic Tender and Examine System, at hrtp://www.e-procurement.soumu.go.jp (last visited Oct. 24, 2004).

123 See generally U.S. General Service Administration Website, Homepage, at http://www.gsa.gov/Portal/gsa/ep/home.do?tabId =0 (last visited Oct. 24, 2004); GSA Advantage! Website, Homepage, at https://www.gsaadvantage.gov/advgsa/main_pages/start_page.jsp (last visited Oct. 24, 2004). 
from contractors (Schedule Contractors). ${ }^{124}$ e-Buy allows Request For Quotes ("RFQ"s) to be exchanged electronically between federal agencies and Schedule Contractors. ${ }^{125}$ For Federal Buyers, "e-Buy maximizes their buying power by leveraging the power of the Internet to increase Schedule contractor participation to obtain quotations that result in best value purchase decisions." 126 For Schedule Contractors, "e-Buy provides greater opportunities to offer quotations and increase business volume for supplies and services provided under their Schedule contracts." 127

Using the e-Buy system, Federal Buyers "may prepare and post a RFQ for specific services and products for a designated period of time."128 Each RFQ is given its own Special Item Number ("SIN"), and Schedule Contractors are "automatically listed under their awarded SIN categories." 129 After Federal Buyers notify all or a part of the Schedule Contractors listed under a particular SIN category, listed Schedule Contractors quote at the eBuy Web site. ${ }^{130}$ Once a particular RFQ has closed, Federal Buyers then "evaluate and accept the quotation that represents the best value." 131 After the Federal Buyers accept a quotation, it may issue an order to the Schedule Contractors. ${ }^{132}$

At the state level, eMaryland M@rketplace is one of the prominent state government procurement portals. It provides the State of Maryland with a tool to expand the pool of Maryland businesses providing goods and services to the state. It achieves efficient procurement activities via the Internet, including posting procurement opportunities, receiving bids, and making purchases. ${ }^{133}$ Government agencies can establish real-time communications and business transactions with vendors in a paperless environment, minimizing administrative costs. The system increases buying power through intergovernmental cooperative procurement and heightens competition across a

124 See GSA Advantage! eBuyWebsite,Homepage, at https://www.ebuy.gsa.gov/advgsa/ebuy_buyer/ ebuy_login.jsp (last visited Sept. 10, 2004).

${ }_{125}$ See U.S. General Service Administration Website, $e$-Tools: $e$-Buy, at http://www.gsa.gov/Portal/ gsa/ep/contentView.do? contentId=11870\&contentType=GSA_OVERVIEW (last visited Oct. 24, 2004).

$126 \quad$ Id.

127 Id.

128 U.S. General Service Administration Website, e-Tools: How Does e-Buy Work?, at http://www.gsa.gov/Portal/gsa/ep/contentView.do?programId = 8456\&channelId = 13828\&ooid=11870\&contentId = 123318pageTypeId =81998content Type =GSA_BASIC\&programP age $=\% 2 F$ pep $\% 2$ program $\% 2 F g s a B a s i c . j s p \& P=F C O C$ (last visited Oct. 24, 2004) .

129 Id.

$130 \quad$ Id.

131 Id.

$132 \quad I d$

133 See eMaryland M@rketplace Website, Homepage, at http://www.emarylandmarketplace.com (last visited Oct. 24, 2004). 
wider spectrum of suppliers. ${ }^{134}$ Sellers achieve more timely communications by accessing one portal to conduct business with participating buyers rather than having to visit thousands of procurement officers throughout the state. ${ }^{135}$ The robust reputation of government agencies enables them to establish online commerce systems that focus on minimizing administrative costs.

\section{SUMMARY}

In the one-to-many transaction stage, reasonable consumers often carefully select a reputed online shop by relying on its reputation signal as a bond. Reputation functions well as an initial verification of reliability of a counterpart at the time of the contract formation. Once a dispute occurs, the threat of reputation loss induces a cooperative solution to the dispute. However, an offline reputation is often imperfect, because it does not offer a system of self-enforcement for the end game stage. Electronic commerce requires much stronger incentives than reputation, and thus reputed site operators still need to offer additional incentives. In this context, credit card transactions unsurprisingly have a dominant position in electronic commerce, as these transactions provide efficient bilateral incentives that subtly maintain a balance between sellers' and buyers' verification demands. The credit card system not only offers a risk verification mechanism (informal relationship-preserving norms), but also offers contracting parties an opportunity to utilize extralegal dispute resolutions by a third party tribunal through the credit card's charge back system (informal end-game norms). On the other hand, electronic money or digital cash is no longer in the mainstream of payment systems, presumably because the system completely or partially lacks a balance of protection for sellers and buyers and does not offer dispute resolution mechanisms.

By contrast, electronic tender systems (one government entity and many bidders) do not necessarily require online incentives other than those for minimizing administration costs. Electronic tender systems seem to be generally categorized as business models that mainly focus on the rationalization of government agencies' administrative processes. Thus, it appears that incentive mechanisms play a lesser role in electronic tender systems. 


\section{Many-to-Many Transactions}

\section{ONLINE SHOPPING MALlS - MALL'S REPUTATION AS A BOND}

An online shopping mall is a Web market place that has many tenant online shops. Like online shopping site owners, each tenant online shop utilizes the credit card system for the shop's risk verification purpose. However, consumers often have difficulty in verifying tenants, because each tenant in an online marketplace is often unknown. The tenant often does not have a sufficiently well known and positive reputation to encourage consumer transactions.

Accordingly, consumers attempt to rely on the reputation of cyber-mall operators. In fact, consumers are carefully choosing highly reputed online malls. For example, Rakuten Ichiba (Rakuten), one of the leaders of fierce competition in electronic commerce in Japan, is a typical illustration of an online shopping mall functioning as a reputational intermediary. ${ }^{136}$ Rakuten implemented a strong policy that only business firms and carefully selected individual business owners are entitled to be tenants of the mall. ${ }^{137}$ Rakuten carefully audits firms before the mall approves them as tenants. After approval, each tenant must comply with the standardized business process in accordance with the Rakuten Merchant Server (RMS) ${ }^{138}$

Yahoo! Shopping presents another illustration. ${ }^{139}$ A merchant who desires to build an online store in Yahoo! Shopping must participate in Yahoo! Small Business. Yahoo! Small Business includes Yahoo! Merchant Solutions, a suite of online tools for creating and managing an e-commerce web site. ${ }^{140}$ A merchant must agree with the Yahoo! Small Business Terms of Service before commencing business. ${ }^{141}$ A Merchant Solution customer must read, understand, and agree with Yahoo! Privacy Policy, ${ }^{142}$ Yahoo!

136 See generally Rakuten Ichiba Website, Homepage, at http://www.rakuten.co.jp (last visited Oct. 24, 2004)[hereinafter Rakuten Homepage].

137 See id. (indicating the application and approval process of a prospective tenant of the Rakuten Ichiba Website).

138 See id.

139 See Yahoo! Shopping Website, Homepage, at http://www.shopping.yahoo.com (last visited Oct. 24, 2004).

140 See Yahoo! Small Business Website, Homepage, at http://smallbusiness.yahoo.com (last visited Oct. 11, 2004). See also Yahoo! Small Business Merchant Solutions, Getting Started Guide, at http://us.dl1.yimg.com/download.yahoo.com/dl/smbiz/doc/ms_getting_started guide.pdf(last visited Oct. 11, 2004).

${ }_{141}$ Yahoo! Small Business Website, Yahoo! Consolidated Terms of Service, at http://smallbusiness.yahoo.com/tos/tos.php (last visited Oct. 11, 2004).

${ }_{142}$ Yahoo! Privacy Website, Yahoo! Privacy Policy: Yahoo! Privacy Center, at http:/privacy.yahoo.com/privacy/us (last visited Oct. 11, 2004). 
Small Business Email Guidelines, ${ }^{143}$ and Yahoo! Store Guidelines. Merchants must comply with the standards found in the Yahoo! Store Guidelines. ${ }^{144}$ Failure to comply with the guidelines may result in removal from the Yahoo! network. ${ }^{145}$

Consumers have two advantages when they transact with a reputable online shopping mall. First, since more tenants are joining such online shopping malls, consumers are more likely to find goods they want to buy. Second, and more importantly, consumers think that each tenant shop is reliable, so long as the reputed online shopping malls maintained a good reputation by only selecting trustworthy tenants. ${ }^{146}$ Consumers assume that a fraudulent tenant would immediately disappear from online shopping malls because the online shopping mall operator would recognize that the success of the mall depends upon the reputation of the tenants as well as the operator. In fact, typical cyber-tenant agreements include various clauses that prohibit tenants from acting in any way that would adversely affect the online shopping mall; breach of the covenants will immediately trigger the termination of the tenant agreement. ${ }^{147}$ Because an online shopping operator is so keen to its own reputation, it rigorously evaluates the tenant's reputation. In sum, a typical online shopping mall with the credit card system as a payment tool has the following bilateral incentives using reputation as bonds (informal relation-preserving stage): (i) buyers verify the information asserted by tenants through the reputation of an online shopping mall, and (ii) tenants verify buyers by way of the credit card authorization mechanism.

${ }^{143}$ See Yahoo! Website, Yahoo! Mail Additional Terms of Service and Guideline, at http://docs.yahoo.com/info/guidelines/mail.html (last visited Oct. 11, 2004); Yahoo! Website, Yahoo! Business Email, Additional Terms of Service, at http://order.sbs.yahoo.com/sbs/tos/bmail_tos.html (last visited Oct. 11, 2004).

144 Yahoo! Small Business Store Website, Yahoo! Store: Yahoo! Store Guidelines, at http://store.yahoo.com/vw/guide.html (last visited Oct. 11, 2004).

145

Id.

${ }_{146}$ For example, the Rakuten's tenant policy permits only a "carefully selected individual business owner" to be a tenant. See generally Rakuten Homepage, supra note 136. Similarly, Yahoo! Shopping implemented the Merchant Ratings and Reviews system. This helps users make informed decisions and improve the Yahoo! shopping experience. Merchant star ratings provide "at-a-glance" information about how other users feel about a merchant based on a 1 to 5 star scale. Merchant reviews are written by users that provide more details about their experience with a particular merchant. See Yahoo! Shopping Website, Yahoo! Merchant Review Guidelines, at http://shopping.yahoo.com/merchrating/general_info.html (last visited Oct. 11, 2004).

${ }_{147}$ See Electronic Commerce Promotion Council of Japan (ECOM) Homepage, Model Agreements for Cybermall -Report 2 (1.0 Version) (1998), located within http://www.ecom.jp/qecom/ecom_e/index.html (last visited Oct. 11, 2004). See also Yahoo! Website, Terms of Service, at http://docs.yahoo.com/info/terms/ (last visited Feb. 15, 2005). 
In addition, online shopping malls need to be equipped with additional incentive devices so that they can offer an informal end-game dispute resolution (informal end-game stage). First, as previously discussed, a credit card chargeback system works as the incentive for substantive contract performance. Second, online mall operators offer the consumer a protection policy in which the operators act as adjudicators. Yahoo! Shopping's Yahoo! Buyer Protection Program is a typical example. ${ }^{148}$ Within sixty days of purchase, a buyer may file a complaint with supporting documents to Yahoo! Shopping if the buyer believes he or she is a victim of fraud and fails to resolve the matter with merchants. ${ }^{149}$ To protect buyers, prospective merchants must be covered merchants that earn and maintain a "minimum 3-star average merchant rating." After the buyer makes the complaint, Yahoo! Shopping's Complaint Resolution Process ("the Resolution Process") handles the claim. The claim administrator investigates the sale and makes a decision within forty-five days of the receipt of the claim. ${ }^{151}$ Measures taken in the Resolution Process are drastic. If the merchant fails to resolve the complaint or to respond within three business days, Yahoo! may take measures to remove the merchant from Yahoo! Shopping, and may even proceed with a complaint in the Yahoo! Buyer Protection Program. ${ }^{152}$ After all steps are taken, if Yahoo! determines "in its sole discretion that the customer has a legitimate claim against the merchant, the customer can apply for reimbursement through the Yahoo! Buyer Protection Program if applicable." 153 This system ultimately supports the full satisfaction of a buyer's claim if his or her claim is determined as positive. ${ }^{154}$

148 See generally Yahoo! Shopping Help Website, Yahoo! Shopping Help FAQ: Yahoo! Buyer Protection program, at http:/help.yahoo.com/help/us/shop/protection (last visited Oct. 11, 2004).

149 Yahoo! Shopping Help Website, What Purchases Are Covered By The Yahoo! Buyer Protection Program?, at http:/help.yahoo.com/help/us/shop/shop-76.html (last visited Oct. 11, 2004). Before filing a claim, the buyer must (i) attempt to communicate directly with the merchant to resolve the problem, and (ii) ask a credit card company to resolve the problem if the buyer is unable to resolve the matter with the merchant. Yahoo! Shopping Help Website, How Does the Buyer Protection Program Work?, at http:/help.yahoo.com/help/us/shop/shop-77.html (last visited Oct. 11, 2004).

150 Yahoo! Shopping Help Website, What is the Buyer Protection Program?, at http://help.yahoo.com/help/us/shop/shop-75.html (last visited Oct. 11, 2004).

151 Yahoo! Shopping Help Website, How Does the Buyer Protection Program Work?, at http://help.yahoo.com/help/us/shop/shop-77.html (last visited Oct. 11, 2004).

152 Yahoo! Help Website, What is the Yahoo! Complaint Resolution Process for the Buyer Protection Program?, at http://help.yahoo.com/help/us/shop/shop-81.html (last visited Oct. 11, 2004).

$153 \quad$ Id.

154 See Yahoo! Media Relations Website, Yahoo! Launches Yahoo! Buyer Protection Program, at http://docs.yahoo.com/docs/pr/release631.html (last visited Oct. 11, 2004). 


\section{E-MARKETPLACES-ESCROW SERVICES}

Probably the most common many-to-many transaction occurs in an emarketplace. The typical e-marketplace is an open platform that is shared and participated in by multiple sellers and buyers. ${ }^{155}$ E-marketplace operators mainly provide negotiation places, but in many cases do not enter into transactions by themselves. ${ }^{156}$ A negotiation occurs in the online marketplace between a seller and a buyer that post offers. If the negotiation is successful, the parties ultimately enter into a sales contract. ${ }^{157}$ The e-marketplace, in a broad sense, has two classifications. First, the auction site, such as eBay ${ }^{158}$ and Priceline.com, has two stages of incentives that facilitate electronic commerce by enabling contracting parties to verify each other. Reputational bonds are a first step incentive in the relation-preserving stage, and alternative dispute resolution systems are a second step incentive in the endgame stage. Second, business-to-business e-marketplaces, such as The

155 See Electronic Commerce Promotion Council of Japan (ECOM) Homepage, Market Research on Electronic Commerce (2001), located within http://www.ecom.or.jp/ecom_e/index.html (last visited Oct. 24,2004 ) (consisting of a joint research by Ministry of Economy, Trade and Industry (METI), Electronic Commerce Promotion Council of Japan (ECOM), and NTT Date Institute of Management Consulting, Inc).

156 Sun Microsystems describes e-marketplaces from the vertical, horizontal, and supply chain perspective.

A vertical e-marketplace provides goods and services to a specific industry . . . Vertical emarketplace technology should strive to provide a particular industry with a neutral platform for providing an automated Internet transaction-based model for made-to-order products. It should enable participating companies to develop better supply chain management, which can significantly reduce costs and enhance supplier relationships, or improve inventory management of raw and finished goods. A horizontal e-marketplace strives for the same overall goals but provides goods and services across many industries rather than a single one. Examples of horizontal e-marketplaces include systems set up for payment services, logistics services, and office supplies.

Sun Microsystems Website, Types of E-Marketplaces, 5 Sun Journal No. 2, at http://www.sun.com/executives/sunjournal/v5n2/feature4.html\#2 (last visited Oct. 11, 2004). Finally, the enterprise supply chain marketplaces "enable an enterprise to deliver the right products at the right time to the right customer. A supply chain e-marketplace typically engages many large software components, including e-procurement and e-distribution modules." Id.

157 In this respect, there seems to be no distinct difference between the basic function of the marketplace and the auction site. However, this article differentiates between the two. The latter is a typical auction site where a bidder, submitting the highest or lowest price, will contract with the counterparty. On the other hand, the former is a business-to-business negotiation platform where contracting parties desire to write relatively discrete contracts.

158 See eBay Website, Homepage, at http://www.ebay.com (last visited Oct. 24, 2004). 
WorldWide Retail Exchange (WWRE) ${ }^{159}$ and GlobalNetXchange (GNX), ${ }^{160}$ primarily seek to reduce direct costs of transactions such as delivery, transportation, or other administrative costs.

Payment and delivery conditions differ according to the type of transaction. In some transactions, payment and delivery conditions are pre-determined via offline negotiations, where the primary role of the e-marketplace is to provide an administration platform rather than actual contract formation. However, merely providing an opportunity for low-cost administration does not make e-marketplaces attractive. Transactors that desire to construct business models over many-to-many transactions will encounter the problem of how to create bilateral incentives. So far, many electronic commerce operators have tried to develop efficient bilateral incentive mechanisms, since the critical problem with e-marketplaces is that both a buyer and a seller are in a stranger-to-stranger relationship without having sufficient information about each other.

E-marketplace owners first attempt to provide reputational bonding tools so that players might easily verify information with respect to their transactions. They may first attempt to limit the players to sophisticated firms, but this would limit business expansion. Therefore, e-marketplace operators seek an alternative reputational intermediary on which each member can rely. E-marketplace operators may try to become intermediaries by intervening in transaction streams. ${ }^{161}$ However, they may have difficulty when they are not able to monitor effectively both sellers and buyers. Thus, e-marketplace operators seek a third-party informational intermediary. Emarketplace operators request the intermediary to offer a bilateral incentive mechanism to enhance or secure contract performance and provide fair distribution of costs and benefits in dispute resolutions. An example of this is using an escrow service.

159 See Worldwide Retail Exchange Website, WWRE Overview, at http://www.worldwideretailexchange.org/cs/en/about_wwre/overview.htm (last visited Oct. 11, 2004). The Worldwide Retail Exchange Website (WWRE) is the premier Internet-based business-to-business exchange for retailers and suppliers, which primarily aims to facilitate, simplify, and rationalize transactions between manufacturers, retailers and suppliers. It currently consists of members from Africa, Asia, Europe, North America and South America with combined annual revenue of more than U.S. $\$ 900$ billion.

160 See GlobalNetXchange Website, Homepage, at https://www.gnx.com/home.jsp (last visited Oct. 11, 2004). "[GlobalNetXchange] is an e-business solution and service provider for the global retail industry." Id. GlobalNetXchange (GNX) assists retailers, manufacturers and their trading partners, including many of the world's largest retailers and manufacturers, in reducing their transaction costs and improving efficiency by streamlining and automating sourcing and supply chain processes.

161 Yahoo! Shopping's Buyers Protection Program is one example of how a site owner becomes an intermediary, but Yahoo! does not intervene in a transaction stream as a contracting party itself. 
Escrow Services: An escrow scheme is one of the most popular incentive mechanisms in many-to-many transactions. ${ }^{162}$ In this escrow account scheme, a seller and a buyer appoint an independent third party as an escrow agent who retains the payment until delivery and inspection are confirmed. An escrow agent is generally an agent of both a seller and a buyer. ${ }^{163}$ The seller has no delivery obligation if the buyer does not pay the purchase price to the escrow agent. On the other hand, if the seller does not deliver the goods, the buyer terminates the contract and gets the money back from the escrow agent. ${ }^{164}$

The escrow mechanism will provide a buyer with the chance to inspect goods delivered in the presence of an escrow agent, so that the buyer may significantly reduce risks of imperfect performance. The escrow agent refunds the purchase money to the buyer when the seller does not deliver the goods in accordance with the contract terms. The buyer may then withhold the payment until the completion of inspection. The seller, on the other hand, secures the purchase price through the escrow mechanism, so that the seller may have a payment condition similar to cash on delivery. ${ }^{165}$

In order to achieve risk-minimizing structures, many-to-many business models often utilize escrow services provided by independent electronic commerce operators. However, online escrow services have "failed to gain much of a foothold because of their higher costs, despite the greater protections they offer." 166 If a transaction is an as is sale, like many secondhand marketplace transactions, the quality of goods will be of little importance. While escrow services seek greater protection of buyers sacrificing sellers, buyers in fact do not desire a stronger bonding mechanism than those offered by credit card systems.

More importantly, an escrow provides an incentive mechanism before delivery, but offers no incentive after delivery is complete. Although an escrow service keeps purchase money in an escrow account and does not pay the money to a seller until the completion of inspections, the service no longer offers any informal dispute resolution system once the purchase money is paid. Further, contracting parties must prepare a more complete and discrete agreement when they use an escrow service, because a third party inspector must rely on a discrete rule in determining whether the buyer

162 For example, Escrow.com is an entity engaged in the escrow business in electronic commerce. See Escrow.com Website, Homepage, at http://www.escrow.com (last visited Sept. 11, 2004).

163 See Fisher v. Comer Plantation, Inc., 772 So. 2d 455, 468 (Ala. 2000).

164 See generally Escrow.com Website, Process Overview: Guiding Buyers and Sellers Safely Through the Online Escrow Process, at https:/www.escrow.com/solutions/escrow/process.asp (last visited Oct. 11, 2004).

165 See generally Sorkin, supra note 89.

166 Id. at 30 . 
executed a complied delivery. Ironically, contract drafting costs are generally higher in electronic commerce, which causes difficulty in creating complete agreements.

\section{Auction Sites-Feedback Systems and Online Payment SYSTEMS}

Auction sites are the leading exponents of e-marketplaces, and now they are widely reputed all over the world. eBay, a leading auction site in the United States, boasts more than ninety-five million registered users on a worldwide basis. ${ }^{167}$ In a typical auction site, contracting parties are strangers. Thus, auction players are required to confirm each other's assertions through verification systems. Since an auction site anticipates a contract between two unknown individuals, its operator tries to establish reputational verification tools. An efficient system of reputational verification is a key for their success.

Feedback Systems: In an online auction, a feedback system offers an incentive mechanism. The system provides both sellers and bidders with an online bulletin board to post information about transactions formatted through the Web site. This gives potential subsequent traders the tools to evaluate the reputation of parties with whom they wish to transact. eBay provides an extensive feedback system where every eBay user has a "Feedback Profile" made up of comments from other eBay users. ${ }^{168}$ Before a bidder bids on an item, the bidder can check the seller's feedback rating. Sellers can also view the feedback profiles of bidders to see how reliable they have been in the past. Similarly, other Web sites such as Epinion.com, ${ }^{169}$ Yahoo! Shopping Auction, ${ }^{170}$ and Amazon.com ${ }^{171}$ provide feedback systems that permit users to post their transactional experiences.

Registered users of eBay grew from two million in December 31, 1998 to ninety-five million in December 31, 2003. eBay Website, eBay Annual Report 2003, located within http://investor.ebay.com/annual.cfm (last visited Oct. 11, 2004) [hereinafter eBay Annual Report 2003]. Among ninety-five million registered users, nearly forty-one million were active users, as compared to 28 million active users at the conclusion of 2002. Id. located within http://investor.ebay.com/annual.cfm.

168 See eBay Website, Feedback Forum, at http://pages.ebay.com/services/forum/feedback.html (last visited Sept. 11, 2004).

169 See Epinions.com Website, Homepage, at http://www.epinions.com (last visited Oct. 24, 2004).

170 See Yahoo Shopping Auctions Website, Yahoo Auctions, at http://list.auctions.shopping.yahoo.com (last visited Oct. 11, 2004).

171 See generally Amazon.com Website, Amazon.com Auctions, at http://s1.amazon.com/exec/varzea/subst/home/home.html/103-2368185-6545437 (last visited Oct. 11, 2004). 
eBay's feedback system has two distinct characteristics. First, the rate of neutral and negative comments is much lower than that of positive comments. As reported by Paul Resnick and Richard Zeckhauser, the feedback provided by buyers using eBay was $99.1 \%$ positive, $0.6 \%$ negative, and $0.3 \%$ neutral. ${ }^{172}$ Similarly, sellers using eBay provided feedback that was $98.1 \%$ positive, $1.6 \%$ negative, and $0.3 \%$ neutral. ${ }^{173}$ The other characteristic is the high rate of bidders and purchasers who post feedback comments. A survey showed that $52.1 \%$ of bidders and $60.6 \%$ of purchasers commented through the Feedback Forum of eBay's Web site. ${ }^{174}$

These figures imply that users often overestimate the rating of another party's reputation because these are accounted for by a norm of reciprocity, where a repeat player is encouraged to post positive feedback for his counterpart in order to elicit a similar response from his counterpart. ${ }^{175}$ While information posted on the Feedback Forum may not always reflect the true disclosure, the forum is still an efficient device to evaluate the risk of prospective transactions. ${ }^{176}$ Users believe that Feedback Forum ratings can approximately predict the probability that obligations are performed substantively. ${ }^{177}$ For users, accuracy of information is not necessarily crucial because transactions in auction sites are often as is transactions, and most users of auction sites are probably risk seeking rather than risk averse. If a player has no negative remark in his past transaction record, other members will perceive him as one with whom it is feasible to transact.

It is assumed that the feedback system successfully fulfills two conditions required for reputation functioning as a hostage. First, it offers a communication place to which reputation is disseminated at minimal costs. Second, it establishes a reputation verification standard that primarily focuses on expelling bad guys from the auction site.

Paul Resnick \& Richard Zeckhauser, Trust Among Strangers in Internet Transactions: Empirical Analysis of eBay's Reputation System, at 11 (working paper for NEBR workshop), at http://www.si.umich.edu/ presnick/papers/ebayNBER/RZNBERBodegaBay.pdf (last visited Oct. 11, 2004) [hereinafter Resnick \& Zeckhauser].

173 Id. at 11 .

$174 \quad$ Id.

175 Cf. Clayton P. Gillette, Reputation and Intermediaries in Electronic Commerce, 62 LA. L. REV. 1165 (2002). There are several explanations as to why users are likely to overestimate. Gillette argues that eBay's instruction to deter defamatory comments might reduce negative comments. Nonetheless, according to Gillette, ease of legal obligation against defamation does not necessarily encourage more accurate and truthful comments because of a herd behavior that the mere presence of multiple negative comments is likely to overstate a trader's low quality-users who found a trader's previous negative information in the Feedback Forum were more willing to attribute a bad transactional result to that trader. Id. at 1191.

177 See generally Resnick \& Zeckhauser, supra note 172. 
Online Payment Systems: While a feedback system provides a contracting party with a chance to evaluate a counter-party's reputation, its incentive mechanisms only serve relation-preserving norms. Although contracting parties need additional informal end-game norms, credit card payments have relatively smaller market share in online auctions. Because auctions are in most cases individual-to-individual transactions, individuals have difficulty in obtaining merchant accounts that enable them to accept payments by credit cards. ${ }^{178}$ Instead, contracting parties use an online payment service as an incentive. ${ }^{179}$ In fact, eBay utilizes PayPal, a subsidiary of eBay, as a payment service intermediary. ${ }^{180}$ Yahoo! and Amazon.com operate their own payment service providers. ${ }^{181}$ These online payment services offer an incentive in which the service providers function as both reputational intermediaries at the informal relation-preserving stage, and dispute mediators at the informal end-game stage. In this sense, the provider's service is similar to that of the credit card system. However, because the online payment service is not regulated, different service providers can arrange different terms and conditions for sellers and buyers.

PayPal is a leading company in online payment solution services, operating in thirty-eight countries with over forty million members. ${ }^{182} \mathrm{~A}$ seller and a buyer must sign up for a PayPal account in order to send or

See National Consumers League Online Auctions Website, Online Auction's 2001 Survey: Summary of Findings, at http://www.nclnet.org/shoppingonline/auctionsurvey.htm (2001) (noting that in only $17 \%$ of the transactions did the buyer give his credit card number directly to the seller). See also, Sorkin, supra note 89 at 7.

179 See National Consumers League Online Auctions Website, Online Auction's 2001 Survey: Summary of Findings at http://www.nclnet.org/shoppingonline/auctionsurvey.htm (2001) (noting that 44\% of those who bought items through auction sites used payment services offered by or through auction sites that facilitated payment by credit card).

180 See PayPal Website, Homepage, at http://www.paypal.com (last visited Oct. 24, 2004).

181 See Sorkin, supra note 89.

182 PayPal currently offers its services to users in 38 countries, including the United States. See eBay Annual Report 2003, supra note 167, located within http://investor.ebay.com/annual.cfm. In fact:

[d] uring 2003, over $\$ 12.2$ billion in total payment volume, or TPV, was transacted on the PayPal platform, consisting primarily of payment to individuals and small businesses trading on eBay and various other online shopping sites. As of December 31, 2003, PayPal had 40 million accounts, compared to 23 million accounts at December 31, 2002.

PayPal has achieved its rapid growth by delivering a combination of user convenience, competitive pricing and customer safeguards. During the year ended December 31, 2003, PayPal's total number of accounts grew by 17 million, an average of 46,000 per day. During this same period, PayPal processed an average of 629,000 payments per day, averaging $\$ 33.5$ million in daily payment volume, with an average payment of $\$ 53$ sent during this period.

Id., located within http://investor.ebay.com/annual.cfm. 
receive payments through the service. ${ }^{183}$ After signing up for a PayPal account, the buyer needs to add a funding source for payments, such as a credit or debit card. The buyer then enters the payment amount and his or her email address. ${ }^{184}$ The payment that the seller receives is automatically reflected in the seller's PayPal account balance. ${ }^{185}$ The seller may use the balance for various purposes, such as sending a payment to someone else, using a PayPal virtual debit card to shop anywhere online, opening a money market reserve fund to earn a return on the PayPal balance, and withdrawing the money to a bank account. ${ }^{186}$

Both the seller and the buyer can verify the reliability of each other through the function of a payment service provider. The payment service provider acts as a reputational intermediary, serving informal relationpreserving norms. The PayPal User Agreement provides that PayPal may set a limit or refuse to provide services to a member, if the member harms PayPal. ${ }^{187}$ In addition, online payment services work as a third party adjudicator that informally settles disputes between sellers and buyers. Sets of rules in the dispute resolution system constitute informal end-game norms. For example, PayPal's Buyer Claimant Policy indicates that PayPal will try to help buyers recover funds from non-complying sellers, and help complying sellers reduce risk of chargeback. ${ }^{188}$ The policy also provides that $\mathrm{PayPal}$ is entitled to investigate an underlying transactional dispute upon receiving a chargeback claim from the buyer. If the seller cannot present sufficient evidence, PayPal is entitled to collect the amount the buyer paid from the seller. ${ }^{189}$

183 See generally PayPal Website, Help Center, at http://www.paypal.com/cgibin/webscr? $\mathrm{cmd}=$ _help-ext\&eloc $=0 \& l o c=4 \&$ source_page $=$ _home\&flow $=($ last visited Oct. 22, 2004)

184 See id.

185 See id.

186 See id.

187 Section 11 of the PayPal User Agreement provides for PayPal's remedial rights as follows:

$[w]$ ithout limiting other remedies, we may update inaccurate or incorrect information you provide to us, contact you by means other than electronically, immediately warn our community of your actions, place a hold on funds in your account, limit funding sources and payments, limit access to an account and any or all of the account's functions (including but not limited to the ability to send money or making withdrawals from the account), limit withdrawals, indefinitely suspend or close your account and refuse to provide our Services to you.

PayPal Website, User Agreement for PayPal Service, at http://www.paypal.com/cgibin/webscr? cmd = $/$ /gen/ua/ua-outside (last visited Oct. 24, 2004).

188 PayPal Website, Buyer Complaint Policy, at http://www.paypal.com/cgibin/webscr?cmd =p/gen/ua/policy_buyer_complaint-outside (last visited Oct. 24, 2004).

189

Id. 


\section{Negotiable INSTRUMENTS-DisCRETE MEMBER AGREEMENTS}

A transaction by use of negotiable instruments is one of the most complicated types of many-to-many electronic commerce. ${ }^{190}$ It is complicated because one negotiable instrument represents rights and obligations of all parties in a transactional chain.

Despite the complexity of negotiable instruments, both Electronic Signatures in Global and National Commerce Act (E-Sign) and Uniform Electronic Transactions Act (UETA) provide legal support for the creation, transferability, and enforceability of electronic records. ${ }^{191}$ The key terms for electronic negotiable instruments are transferable record and control. ${ }^{192}$ The transferable record is an electronic equivalent of a paper note or document. ${ }^{193}$ For an electronic record to qualify as the transferable record, its issuer must expressly agree that the electronic record is to be considered a transferable record. Control, the other key term, acts as a substitute for possession in the paper world. ${ }^{194}$ Control requirements are satisfied "if a system employed for evidencing the transfer of interests in the transferable record reliably establishes that person as the person to which the transferable record was issued or transferred." 195

Although E-Sign and UETA have opened the door to the use of electronic negotiable instruments, these instruments seem to be premature and are still under development. ${ }^{196}$ These Acts do not address issues related to endorser liability, warranty liability, and effects of taking a transferable record on the underlying obligation. ${ }^{197}$ Instead, the contract must address these issues and bind any player in the chain of transactions. ${ }^{198}$ Current technology "[does] not try to create a new mechanism approximating possession of a piece of paper as a system for tracking ownership." In order to satisfy the control requirement of these acts, they require a trusted third party registry system that administrates and stores transferable records. ${ }^{199}$ In

See Jane Kaufman Winn, Couriers Without Luggage: Negotiable Instruments and Digital Signatures, 49 S.C. L. Rev. 739 (1998); Jane Kaufman Winn, What Is a Transferable Record and Who Cares?, 7 B.U.J. SCI. \& TECH. L. 203 (2001) [hereinafter Winn, What is a Transferable Record and Who Cares]. See also Maggs, supra note 3 (presenting a general discussion of negotiable instruments).

See UETA $\$ 16$.

See 15 U.S.C. $\$ 7021$; UETA $\$ 16(a)$.

See UETA $\$ 16$, Comment 3 .

15 U.S.C. $\$ 7021$ (b); UETA $\$ 16(a)$.

See Winn, What is a Transferable Record and Who Cares?, supra note 190.

UETA 16, Comment 4.

Id.

See Winn, What is a Transferable Record and Who Cares?, supra note 190. 
any event, some contract arrangements are necessary for implementing business models with electronic negotiable instruments. This implies that only players bound by a member agreement can be prospective users of electronic negotiable instruments.

Despite the above difficulty, some businesses have already started pilot operations. One of the most large-scale attempts at establishing electronic negotiable instruments is found in real world export and import practices. ${ }^{200}$ In Europe, Bolero.net is trying to achieve this purpose through the company's Trusted Trade Platform. ${ }^{201}$ The Trusted Trade Platform provides a basic infrastructure to exchange electronic trade documents via the Internet. ${ }^{202}$ The Bolero Bill of Lading is "created, transferred, and surrendered" through the Trusted Trade Platform. ${ }^{203}$ The Bolero Title Registry provides a repository and workflow for the creation and transfer of negotiable title documents, and therefore allows transactors to exchange the rights and obligations contained in a Bolero Bill of Lading. ${ }^{204}$ The Bolero Title Registry and the Bolero Bill of Lading "provide a fully functional equivalent to the paper Bill of Lading." 205

As a contractual structure, Bolero established the Rulebook, a contractually binding set of rules that all users of the Bolero service are required to sign. $^{206}$ This Rulebook is "a multi-lateral contract that binds each user to every other user in relation to their use of the Bolero service." 207 It provides necessary terms and conditions that codify the key elements of the Bolero

See Chester D. Hopper, Carriage of Goods and Charter Parties, 73 TUL. L. REV. 1697, 1729-30 (1999) (discussing electronic bills of lading).

201 See Bolero Website, Homepage, at www.bolero.net (last visited Oct. 11, 2004). See also Bolero Association Website, at http://www.boleroassociation.org (last visited Oct. 11, 2004). Bolero "is a neutral secure platform enabling paperless trading between buyers, sellers, and their logistics service and bank partners." Bolero Website, Homepage, at www.bolero.net (last visited Oct. 11, 2004). The platform of Bolero is operated by Bolero International Limited, with the administrative support of Bolero Association Limited. Bolero International Limited is responsible for the operation of Bolero.net service. Bolero Association Limited administers "the enrollment process and the Bolero Rule Book (the governing document for all users of the Bolero System)," member disciplinary procedures, and other administrative issues in order to support Bolero.net's goal of creating the electronic alternative to paper-based trade. Bolero Association Website, Homepage, at http://www.boleroassociation.org (last visited Oct. 11, 2004).

202 See Bolero Website, Solutions: Bolero's Trusted Trade Platform, at http://www.bolero.net/solutions/trade_platform/index.html (last visited Oct. 11, 2004).

203 Bolero.net, Solutions: Title Registry, at http://www.bolero.net/solutions/trade_platform/titleregistry.html (last visited Oct. 11, 2004).

$204 \quad$ Id.

$205 \quad$ Id.

206 See Bolero.net, Solutions: Rule Book, at http://www.bolero.net/solutions/trade_platform/rulebook.html (last visited Oct. 11, 2004).

$207 \quad$ Id. 
service, including a provision that treats users' electronic communications as valid and makes a message bearing digital signature legally binding. ${ }^{208}$ It also "provides the legal rules that underpin the system enabling transactions of the Bolero Bills of Lading ... [and] . . . also includes detailed Operating Procedures and a few Operational Rules involving precise and technical points of user-to-user operations."209

Japan has similarly attempted an electronic documentation delivery system. The Trade Electronic Data Interchange ("TEDI") project is a government initiative project intending to establish a Japanese standard model for electronic bills of lading. It is "achieving greatly enhanced efficiency and reduced costs in trade practices through the computerization of trade-related documents and the use of the Internet." 210 To ensure the smooth functioning of the TEDI system, the management entity, Japan Electronic Trade Service, Inc. ("JETS"), works as a certificate authority ("CA"), which issues public key certification to subscribers for verification of the electronic signature used on TEDI. It is also expected to work as a repository service provider ("RSP"), which provides accurate management, tracks possession transfer, and maintains title holder information for trade documents, including shipment information documents that provide the same function as bills of lading. ${ }^{211}$

As the TEDI system is a trade system relying on participants' relationship of contracts, users within a trade chain are required to: "(a) exchange documents and information electronically, (b) be bound by an electronic data record of the status of goods being shipped in a trade transaction, and (c) to use certain common protocols and outside service providers to assure consistency and integrity in the operation of the system."212 These projects are aimed to make the export and import documentation process more rapid through electronic documentation exchange systems. In this respect, the current electronic documentation delivery system appears to emphasize its effects on the reduction of ex ante contract documentation costs, together with other administration costs. Because documents required for shipment, such as letters of credit and bills of lading, are already standardized offline,

$208 \quad I d$

$209 \quad 1 d$

210 Japan Electronic Trade Service, Inc., Website, About Senvice: Japan Electronic Trade Service: The Strength Behind TEDI, at http://www.jets-tedi.com/e/01/service.htm (last visited Oct. 11, 2004). The Trade Electronic Data Interchange (TEDI) system presupposes trade chains consisting of a seller, a buyer, a bank, and a carrier.

2:I See TEDI-Club Website, Legal Framework at http://www.tediclub.com/english/project/index2.html.

212 Interchange Agreement is currently at http://www.tedianet.com/e/down/down_manual.html (last visited Oct. 22, 2004). 
electronic commerce is able to incorporate those documentation processes in its business model. However, it is still questionable whether the cost reduction by establishing the online documentation process actually outweighs the increase of costs in building the online system. In particular, as shipping documents, such as letters of credit and bills of lading, are supposed to be circulated in a trade chain consisting of a seller, a buyer, and a carrier, the larger membership is a precondition that the system may be able to function as a cost reduction device. Thus, it appears that it takes much longer for the electronic documentation exchange system to attain popularity.

\section{SUMMARY}

A business model has difficulty in establishing efficient incentive mechanisms when two innocent parties transact without face-to-face contact. ${ }^{213}$ How does the model encourage two innocent parties to shake hands? Currently, businesspersons are developing two different strategies. One is to reduce ex ante costs by managing administration processes effectively. The other is to provide businesses with incentives to create transactions. If formal legal enforcement is relatively difficult because of high drafting costs and high enforcement costs, contracting parties are more likely to seek alternative informal norms created by incentive mechanisms. Typical auction sites, such as eBay, are keen to establish optimal bilateral incentives, such as an online payment system and a feedback mechanism.

On the other hand, the business-to-business type of business models in many-to-many transactions is more likely to focus on reducing administrative costs rather than deploying incentives. Indeed, leading e-marketplace sites and electronic negotiable instrument providers seek to establish openend EDI platforms by enhancing administration tools.

\section{CONCLUSION}

This article has identified various incentives underlying currently prevailing business models for electronic commerce. Institutional analysis of business models provides a clue to the contracting parties' intentions in creating contracts. The Internet's global and automated nature made lowvalue, stranger-to-stranger, and long-distance transactions possible, but these

213 Indeed, most of consumer frauds have occurred in many-to-many transactions. The National Consumers League's Internet Fraud Watch (IFW) reported that the amount of consumer fraud reported to IFW reached $\$ 14$ million in 2002 , "with more than $\$ 13$ million in losses in the online auction category alone." National Consumers League Website, Online Auctions Dominant Consumer Fraud, at http://nclnet.org/internetfraud02.htm (last visited Oct. 11, 2004). 
transactions made both ex ante contract specification and ex post enforcement difficult, and increased the possibility for opportunism. Based on this understanding, business models of electronic commerce are classified according to which costs, ex ante or ex post, are emphasized as a target of cost engineering. This article revealed that a typical business-to-consumer business model emphasizes its cost reduction targets on ex post enforcement costs. In order for business models to function in stranger-to-stranger, low-value circumstances, those models often have two stages of incentives, namely the relation preserving incentive, and the end game incentive.

Two stages of incentives create two stages of informal norms. The first norm utilizes a reputational bond that gives contracting parties an efficient tool to properly evaluate risks in underlying transactions, and encourage substantive contract performance (informal relation-preserving norm). For example, a simple online shopping site, one of the most common examples of one-to-many transactions, may be more successful if the site owner is a reputed enterprise that already obtained a high reputation with the historical success of its offline business. Consumers feel that the reputed enterprise will try to resolve the dispute faithfully for fear of the informal sanction of reputational damage.

However, the offline reputation of a site owner is not a perfect assurance mechanism. Contracting parties seek an additional assurance mechanism so that buyers may be able to settle a dispute at the end-game stage at lower costs. In this context, a traditional paper-based alternative dispute resolution (ADR) does not function effectively in electronic commerce because an additional offline procedure is likely to destroy the electronic commerce advantage where whole procedures are completed online. For this reason, electronic commerce must employ online ADR in its online transactional procedure. As the third party adjudicator is also an independent party with his own interest, norms that apply to the dispute are likely to be informal rather than formal (informal end-game norm).

Nevertheless, this does not mean that a formal legal enforcement is no longer necessary in electronic commerce. Even though contracting parties rely on informal norms, a party may seek formal legal enforcement when the other party acts opportunistically. Accordingly, the unique nature of the incentive type of business model is its two steps in end-game norms. When a consumer requests a chargeback to a card issuer in a credit card transaction, the card issuer often accepts the chargeback and asks the merchant to provide evidence of its substantive performance. When the merchant fails to show the sufficient evidence, the card issuer then does a chargeback to the merchant (informal first end-game norm). However, if the merchant finds that the consumer tries to exploit the system by using informal norms, the 
merchant often wants courts to enforce strict formal norms (formal second end-game norm).

Consequently, business models of electronic commerce often have three stages of dispute-resolution where contracting parties try to achieve an optimal balance between formal and informal norms. Contracting parties adjust themselves to a risk verifiable situation via bilateral incentive mechanisms. Business models of electronic commerce are cleverly designed to reflect such demand for efficient incentive mechanisms.

This total mechanism of efficient allocation between formal and informal norms in electronic commerce may justify courts' formalistic interpretation of a website's displayed legal terms. Courts must be more concerned that intervening in online contracts may destroy the optimal balance between the formal and informal norms and ultimately hinder the sound development of transactions. Courts should also be sensitive to the background mechanism of business models. As the contract formation process in electronic commerce is automated, with no human intervention, an electronic commerce operator often expresses its intent for online transactions through incentive mechanisms within its business model. Thus, in deciding whether there has been exploitation, courts must consider whether legal terms are well designed under the overall system of incentives embedded in the adopted business model. 